\title{
FIELD OR FIELDS? BUILDING THE SCAFFOLDING FOR CUMULATION OF RESEARCH ON INSTITUTIONAL FIELDS
}

\section{CHARLENE ZIETSMA}

York University

4700 Keele Street

Toronto, ON, CANADA M3J 1 P3

(416) 736-2100, Ext. 77919

Correspondingauthor: czietsma@schulich.yorku.ca

PETER GROENEWEGEN

VU University

De Boelelaan 1081,

1081 HV Amsterdam, Netherlands

t (31) 205986914 m (31) 612061444

p.groenewegen@vu.nl

DANIELLE LOGUE

University of Technology Sydney

15 Broadway, Ultimo, NSW 2007

+61295143659

Danielle.Logue@uts.edu.au

C. R. (BOB) HININGS

University of Alberta

chinings@ualberta.ca 


\title{
FIELD OR FIELDS? BUILDING THE SCAFFOLDING FOR CUMULATION OF RESEARCH ON INSTITUTIONAL FIELDS
}

\begin{abstract}
The concept of an institutional field is one of the cornerstones of institutional theory, and yet the concept has been stretched both theoretically and empirically, making consolidation of findings across multiple studies more difficult. In this article, we review the literature and analyze empirical studies of institutional fields to build scaffolding for the cumulation of research on institutional fields. Our review revealed two types of fields: exchange and issue fields, with three subtypes of each. We describe their characteristics. Subsequently, we review field conditions in the extant literature and develop a typology based on two dimensions: the extent of elaboration of institutional infrastructure and the extent to which there is an agreed upon prioritization of logics. We discuss the implications of field types and conditions for isomorphism, agency, and field change, based on a review of the literature that revealed six pathways of field change and the factors affecting them. We outline a research agenda based on our review highlighting the need for consolidation of field studies and identify several outstanding issues that are in need of further research.
\end{abstract}




\section{INTRODUCTION}

The concept of an institutional field is one of the cornerstones of institutional theory, an “increasingly useful level of analysis" (Reay \& Hinings, 2005: 351) and "the level of most significance to institutional theory" (Scott, 2001: 83). It functions as a mid-level construct encompassing other concepts that together characterize institutional explanations of organizational behavior. A field is defined as a community of organizations that interact together "frequently and fatefully" (Scott, 1995: 207-208) in a "recognized area of institutional life" (DiMaggio \& Powell, 1983: 148). Fligstein and McAdam (2012: 3) argue that the field is "the basic structural building block of modern political/organizational life". Scott (2014: 219) says that "no concept is more vitally connected to the agenda of understanding institutional processes and organizations than that of organization field".

In spite of this centrality, there is a need for more clarification on what constitutes an institutional field as well as consolidation of work that has been done (Gray \& Cooper, 2010). Research on institutional fields has developed a wide variety of insights, yet the concept's usage has been stretched both theoretically and empirically. To clarify and consolidate, we review existing theoretical definitions and research on fields. This review shows that there is confusing overlap in some areas, and further, that empirical usage of the concept of institutional fields often diverges from theoretical definitions. By reviewing conceptualizations and findings across studies of institutional fields, we attempt to bring clarity to the concept of field and its relationship to other institutional phenomena, and thereby increase its utility.

Our review demonstrates the lack of a systematic classification of field differences, though many studies independently illustrate that differences in field types and conditions exist, and they matter for field-level processes and field-located phenomena. Indeed, this lack of 
attention to field-level differences impairs our ability to cumulate research and make specific predictions about field-level phenomena. Our review shows that the lack of a focus on differences and similarities in fields is a significant hurdle to the development of a theory of fields.

To deal with this issue, we integrate insights across reviewed papers to identify different types and conditions of fields. Our hope is that this classification of the literature can serve as theoretical scaffolding and stimulate new research and consolidate insights on categories of institutional fields. Such a review enables more effective integration and refinement of knowledge about field-level processes, such as formation, isomorphism and change, and it enables connections with other research themes in institutional theory, such as institutional complexity, agency and emotions. Our review is particularly focused on meso-level fields, that is, those fields that operate at the inter-organizational level within a recognized domain, or "area of institutional life" (DiMaggio \& Powell, 1983). This excludes societal fields, which focus on cross-cutting issues at a more macro level, often including multiple fields (see, e.g., Evans \& Kay, 2008). It also excludes a focus on intra-organizational relationships.

We begin by reviewing key theoretical definitions from Bourdieu (Bourdieu \& Wacquant, 1992), DiMaggio and Powell (1983); Scott (2014); Wooten and Hoffman (2008); Fligstein and McAdam (2012) and others. We highlight the similarities and differences in these definitions and in the operationalization of institutional fields in the literature, arguing that we are treating somewhat disparate phenomena as if they were the same thing. As a result, we are unable to cumulate knowledge effectively. We specify the differences, then examine the implications such differences might have.

From this we develop a classification system of field types and field conditions, 
emphasizing differences in the institutional infrastructure and the settledness of the logic prioritization of the various fields and their implications for isomorphism. We then examine agency within institutional fields, considering field positions and roles and how they are affected by field types and conditions. We then consider the implications of field types for the field-level processes of diffusion and change and the implications of field conditions for pathways of change. Finally, we suggest a research agenda as a way forward in the study of fields.

\section{Definitions}

The organizational field is "the central construct" (Wooten \& Hoffman, 2008: 130) of institutional theory - the field is the location of many of the institutions that guide everyday behavior. The field represents a "local social order" (Fligstein, 2001: 107) of actors who consider one another in their daily activities (McAdam \& Scott, 2005). The field is "characterized by an orienting principle or goal" (Evans \& Kay, 2008: 973). It is the bounded area within which meanings are shared (Glynn \& Abzug, 2002) and specific institutions operate. Institutional fields are presumed to be the predominant source of pressures for institutional conformity and the site of institutional embeddedness, which we argue is the core idea of institutional theory. They are also enabling: the institutional infrastructure of organizational fields comprise the mechanisms of social coordination by which embedded actors interact with one another in predictable ways. However, despite its long history (see Scott, 2014, for a discussion), the field concept has remained rather loose in definition, and as a result, its explanatory power is underutilized. In order to be more theoretically useful, the organizational field construct requires substantial consolidation and clarification (Gray \& Cooper, 2010).

Several definitions of the field are used in the organizational literature, and fields are variously labeled institutional fields (Wooten \& Hoffman, 2008), organizational fields (Scott, 
2014), or strategic action fields (Fligstein \& McAdam, 2012). Most institutional scholars use the definition of DiMaggio and Powell (1983: 148), saying that fields comprise "a recognized area of institutional life: key suppliers, resource and product consumers, regulatory agencies and other organizations that produce similar services or products", a definition that emphasizes the kinds of actors in a field, and which assumes a commercial context by its emphasis on services or products. Scott uses a broader definition, capable of encompassing a broader array of field types, which emphasizes common culture and networks. He defines the field as "a collection of diverse, interdependent organizations that participate in a common meaning system" (Scott, 2014: 106). Some authors either define or operationalize the field more narrowly as the set of "organizations that produce related outputs, use related resources, and rely on similar technologies", occupying the same or similar niches (Gibbons, 2004: 938), without reference to interaction partners. ${ }^{1}$

Fields only exist to the extent that they are institutionally defined (DiMaggio \& Powell: 1983). The process of institutional definition, or "structuration," consists of four elements, according to the authors: an increase in the extent of interaction among organizations in the field, implying a network and a boundary; the emergence of sharply defined inter-organizational patterns of domination and coalition, implying status hierarchies among actors; an increase in the information load with which organizations in a field must contend, implying shared meanings and practices among field members; and the development of a mutual awareness among participants in a set of organizations that they are involved in a common enterprise, implying shared identity. Scott (2014) adds other indicators of structuration, including the extent of agreement on institutional logics, defined as the "set of material practices and symbolic constructions" (Friedland \& Alford, 1991: 248) that prescribe behavior within fields (Thornton, Ocasio, \& Lounsbury, 2012), isomorphism of organizational forms and greater clarity of

\footnotetext{
${ }^{1}$ We later define these as populations.
} 
organizational boundaries. A flurry of studies has dealt with the manner in which fields and field processes affect organizations and are affected by them, and how organizational logics are anchored in field-level interactions. The effects of fields on homogenizing organizations through isomorphic pressures has been addressed extensively in the early years of neo-institutionalism, utilizing coercive, mimetic and normative pressures identified in the seminal article by DiMaggio and Powell (1983; Mizruchi \& Fein, 1999).

In contrast to the sense of similarity among actors emphasized by Scott's definition and implied by DiMaggio and Powell's notion of structuration, other actors emphasize conflict and struggle within fields. Bourdieu, for example, viewed the field as "networks of social relations, structured systems of social positions within which struggles or maneuvers take place over resources, stakes and access" (Oakes, Townley, \& Cooper, 1998: 260). Bourdieu's field concept is applied to the societal level and attempts to explain individual action. For his society-level domains such as scientific field, he emphasizes four types of capital (social, economic, symbolic, cultural) that determine actors' power within a specific field and their possibilities for action (Wacquant, 1989; Bourdieu, 1985).

While Scott's conception of a field emphasizes stability, Bourdieu's conception instills the idea of continuous flux in his broad societal fields as actors compete over meanings, resources, boundaries, decision-making authority, etc. For example, "the scientific field is the locus of a competitive struggle, in which the specific issue at stake is the monopoly of scientific authority" (Bourdieu, 1975: 19), while the bureaucratic field is "the space of play within which the holders of capital (of different species) struggle in particular for power over the state" (Bourdieu, 1999: 58). Shifting the society-level institutional insights of Bourdieu, Fligstein and McAdam (2012: 13, 14) describe field constituents in three categories: incumbents, challengers 
and (internal) governance units. Field-level processes highlighted by Fligstein and McAdam focus on strategic action through framing, in the hope of finding resonance with other field members (2012: 17). Extending Bourdieu, Fligstein and McAdam (2012: 3) argue that "any given field is embedded in a broader environment consisting of countless proximate or distal fields as well as states, which are themselves organized as intricate systems of strategic action fields". In shifting the debate in this generic direction, the boundary of fields determined by exchange, as in the definitions common in organization theory, is relaxed. While this sociological approach might prove a fruitful shift for future research, most of the work we review below is built on the use of the field concept developed in organization theory, implying interaction, a recognizable domain of exchange, and the emergence, establishment or change in such fields.

With the budding attention to change in institutional studies, research started to appear that follows the line of contention between field members stressed in sociological approaches focusing on power struggles and framing contests. Hoffman (1999: 351) advanced this new direction in fields, arguing that an organizational field "forms around a central issue — such as the protection of the natural environment — rather than a central technology or market ... fields become centers of debates in which competing interests negotiate over issue interpretation. As a result, competing institutions may lie within individual populations (or classes of constituencies) that inhabit a field". He related the example of chemical manufacturers and environmentalists who influenced one another in a common field, but did not share the same beliefs and attitudes. He emphasized that fields may change when new issues trigger changes in field membership. Recently Meyer and Höllerer (2010) added to the theorizing on issue fields by combining the use of the definition of Powell and DiMaggio with more attention to the power dynamics in issue 
fields. They added to Hoffman's concept in two ways, stressing that opponents and proponents need to attend to framing as well as to the need to mobilize outside the boundaries of a specific issue field in order to settle disputes.

These various definitions suggest that we are treating somewhat disparate phenomena as if they were the same thing. Specifically, many studies assume common logics that exist at the field level and guide behavior. For example, Greenwood and Suddaby (2006: 28), define the organizational field as "clusters of organizations and occupations whose boundaries, identities and interactions are defined and stabilized by shared institutional logics". Yet in issue-based fields, as Hoffman identified, one would not expect a common logic to operate at the field level, but instead to operate at the level of a specific sub-population within the field, such as an industry or a profession or a social movement. A major area of study in the past few years, institutional complexity, reinforces this idea: fields may include multiple logics (Dunn \& Jones, 2010; Greenwood, Raynard, Kodeih, Micelotta, \& Lounsbury, 2011; Reay \& Hinings, 2009; Thornton et al., 2012). Yet, the basic assumption of institutional theory remains: that field-level logics or normative and cognitive structures constrain field members, making some actions or meanings either unthinkable or inappropriate. Bourdieu's approach features these contradictory insights as well—while fields are seen as sites for competitive struggles over meanings, stakes and resources, they are also seen to structure motives, identity, values and practice through fieldlevel logics (Bourdieu, 1985; Oakes, et al., 1998).

So what do these differences in approach mean for 'building the scaffolding' for a more cumulative approach to research on institutional fields? Are the differences in definitions so severe that we have to accept that they are not compatible? At one level, the incompatibility seems great, particularly in the difference between Hoffman and the others. Yet, there is a basic 
degree of commonality in the approaches of DiMaggio and Powell, Scott, Fligstein and McAdam, and Bourdieu.

First, there is the idea that fields are made up of actors who are in relationship with each other and that those relationships are structured around common meanings and common interests. Thus, there is an emphasis on a common culture and shared networks. Second, there is the idea that fields have boundaries that are established both through common meaning systems and the intensity of relationships within a field compared to outside of it. Third, a very important element in Bourdieu, and also contained in DiMaggio and Powell, is the notion that fields have hierarchies of status and influence; all actors are not equal. Fourth, the existence of differential power, influence and status, means that there is contestation, competition and struggle, something that is emphasized by Bourdieu but has also become more important in studies of change in fields (Greenwood, Oliver, Sahlin \& Suddaby, 2008; Wooten \& Hoffman, 2008). All of these elements can be part of, and utilized in an approach to, understanding fields in both (relative) stasis and change.

Hoffman's conceptualization of fields as forming around issues rather than technologies or markets suggests a more fluid idea, with fields including new and often competing members and subgroups, connecting with Bourdieu's notion of struggles, politics, vested interests and agency. His definition accords with a change in theoretical emphasis from stability to change in institutional theory in the late 1990s and following, and it may better reflect social changes brought about in part by the internet, as Powell, Oberg, Korff, Oelberger and Kloos (forthcoming) note: “organizational fields ... are more dynamic, boundaries are more porous, different organizations have come to populate them and the power differentials among members have been altered". Yet Hoffman's view of fields as issue arenas brings together in one field sets 
of actors who have commitments to, and embeddedness within, very different institutional logics and structures, suggesting a field that is by no means settled or uniformly constraining. Without accounting for these differences, we risk misunderstanding the nature of field pressures and the consequent effects on institutional dynamics.

Thus, we essentially work with the more standard definitions of fields, but while the different approaches emphasize different elements, they are, in principle, compatible. To understand differences between fields, field evolution and change, and especially to enable the cumulation of knowledge, it is necessary to combine the various approaches while gaining insights from their differences. Our purpose is to utilize these elements to first analyze different field types, and secondly to analyze field evolution and change. We draw our findings from a systematic review of a set of field studies. To produce this set, we chose 1983 as our starting point to correspond with DiMaggio and Powell's introduction of the term 'field' and we chose December 2015 as our end point. We chose Academy of Management Journal, Administrative Science Quarterly, Journal of Management Studies, Organization Science and Organization Studies to represent the top empirical organizational journals with a history of publishing work on institutional theory. The articles were generated by searching the Web of Science database using the following search terms for the journals in question: "organi\$ational field*" and "institutional field*". Each article was then reviewed by at least one of the authors to determine if it met the following criteria: 1) it included empirical studies; 2) it focused on the field level of analysis, and 3) attention was paid to the actors in the field. A first pass identified those articles that were easily categorized as in or out of the relevant set. Remaining articles were reassessed by two or more other authors to determine whether or not they met the criteria for the study. Our search identified 110 articles, which we then systematically analyzed, as shown in Appendix 1. 


\section{Field Types}

While early studies of institutional fields emphasized isomorphism within fields, more recently, most studies focus on institutional change. While early studies of change often featured the heroic efforts of institutional entrepreneurs changing inertial institutional fields, the literature now acknowledges that fields are often complex (Greenwood et al., 2011) and pluralistic (Kraatz \& Block, 2008), yet there has been little attempt to systematically portray the importance of differences in field types or conditions for field processes. While the literature differentiates between 'emerging' and 'mature' fields, studies of institutional change make it clear that even mature fields become unsettled and change over time (see e.g., Greenwood, Suddaby \& Hinings, 2002; Hoffman, 1999; Munir, 2005; Reay \& Hinings, 2005; Sauder, 2008). Scott (2014) argues that fields vary one from another, as well as over time; thus, a comparative lens is necessary. What we see in the empirical literature on fields is very little specification of the kind of field being studied, with the assumption that a field is a field is a field. But it is not possible to truly cumulate knowledge on fields if scholars are unclear about the nature of the field they are studying and how it is similar to or different from those studied by other scholars. In this section, we review different types of fields and field conditions in order to cumulate insights into the effects field types and conditions have on processes of evolution and change. We hope this classification will stimulate further research distinguishing field differences and their effects.

Fields have been empirically operationalized by analysts in different ways, involving different configurations of membership. Some researchers include members from specific industries or sectors (Tolbert \& Zucker, 1983), others focus on members of social movements (Barley, 2010; Diani, 2013; van Bommel \& Spicer, 2011) and many others analyze industry members and their interaction partners including producers, users, regulators, publics, etc. 
(Farjoun, 2002; Reay \& Hinings, 2009). Some examine institutional processes among those who share some point of commonality even across sectors, such as geography (Glynn, 2008;

Lounsbury, 2007; Marquis, Glynn \& Davis, 2007), or identity characteristics, such as being major multinationals (Kostova, Roth, \& Dacin, 2008), Fortune 500 members (Briscoe \& Safford, 2008), or major U.S. employers (Briscoe \& Murphy, 2012). These differences are likely to result in analysis showing different effects on field processes. Thus, in terms of the definitions of fields that we previously reviewed, we would expect there to be differences in the purposes of fields; the boundaries around them; the homogeneity or heterogeneity of actors within them; the structure of relational networks between members; the number, complementarity and compartmentalization of logics in the fields; and in the nature of the collective identity in the field. These differences will affect field-level processes such as isomorphism, diffusion and change. Yet most studies dealing with fields do not systematically examine the nature of the field that they are defining and use it only as a 'backdrop' for the analysis of field-level processes or organizational responses to fields.

We recommend using different terms for exchange field versus issue field, referring to the purpose fields serve. ${ }^{2}$ Because these two types of fields comprise the majority of research on fields in organization theory, we describe them below, along with the populations that comprise subfields within them, though we recognize that other types of fields exist, such as policy fields, defined as "the set of elements in a specific environment that directly shape local public service provision" (Stone \& Sandfort, 2009: 1056) ${ }^{3}$.

\footnotetext{
${ }^{2}$ Pizarro (2012), cited by Scott (2014), referred to issue fields as “contested” fields, and DiMaggio \& Powell fields as "sectoral fields".

${ }^{3}$ Fligstein (2001) refers to governments as a set of fields that interact with markets, another set of fields. Others have focused on geographic fields (Diani \& Pilati, 2011; Glynn, 2008; Lounsbury, 2007; Marquis et al., 2008), or fields bounded by identity characteristics, such as multinational corporations (Kostova et al., 2008) or the 100 largest nonfinancial companies (Fligstein, 1990; 1991).
} 
Populations and exchange fields. Populations are "a collection or aggregate of organizations that are 'alike in some respect,' in particular, to a class of organizations that are relatively homogeneous in terms of environmental vulnerability", (Scott, 2014, citing Hannan \& Freeman, 1977: 934; 1989), comprising "a recognized area of organizational life", such as nanotechnology firms (Meyer, Gaba, \& Colwell, 2005) or the Belgian horticultural industry (Lepoutre \& Valente, 2012). Our use of the term populations is thus largely consistent with the use of the term in the literature on organizational ecology, which defines populations as those organizations that manifest the same organizational form or identity, usually within a geographical region (Freeman \& Audia, 2006). It is also consistent with the usage of the term by Purdy and Gray (2009), who described a population of dispute resolution organizations within an emerging field of dispute resolution. In network terms, populations are in structurally equivalent positions within fields; they have the same type of relations with similar others. Industry populations include organizations that produce the same products and services, such as information technology (Murray \& O'Mahony, 2007), often with geographic bounds such as Israeli high technology (Zilber, 2006) or Boston or New York mutual funds (Lounsbury, 2007), as clear national and regional differences in populations have been found (Faulconbridge \& Muzio, 2016; Marano \& Kostova, 2016). Social movement populations include the set of organizations that are focused on activism on the same or a broadly similar issue, such as environmentalism (Child, Lu, \&Tsai, 2007), slow food (van Bommel \& Spicer, 2011), gender equality (Clemens, 1993), or LGBTQ rights or identities (Armstrong, 2002; Briscoe \& Safford, 2008). Professional populations include the members of a specific profession, such as accountants (Greenwood et al., 2002); physicians, nurses (Reay, Golden-Biddle \& Germann, 2006) or lawyers (Greenwood \& Suddaby, 2005). 
Exchange fields refer to fields that, consistent with the DiMaggio and Powell (1983) definition, contain a focal population of actors and their interaction or exchange partners (suppliers, customers, etc.). Within exchange fields, populations, rather than the full set of field members, are more likely to share practices and norms, common meaning systems and references to a common identity (Dhalla \& Oliver, 2013). Mimetic forces apply to populations within exchange fields because the relatively homogenous actors in populations share environmental vulnerabilities and demands for legitimacy from the same regulators, similar customers, suppliers, demand conditions, etc. For example, members of the soft drink industry will share more practices, norms, identity and meaning systems with each other than they will with the restaurants and retailers they sell to, or the aluminum can and water suppliers they purchase from. ${ }^{4}$ Exchange partners, such as the retailers in the previous example, will have their own institutional milieu with their own institutions and institutional pressures, though they will share some meanings and practices, particularly around exchanges, such as coordination rules practices and standards, with the soft drink industry members. Thus, it is members of a population that are most likely to share meanings, norms and practices, and environmental responsibilities.

This homogeneity does not imply lack of conflict in populations, however, as members of populations compete with one another over status and resources in front of the "audiences" of their interaction partners (Freeman \& Audia, 2006), who exist within the exchange field. Exchange fields thus contain homogeneous actors as well as other heterogeneous actors. In

\footnotetext{
${ }^{4}$ Note that even within a population there are usually divisions representing specific niches, and meanings and practices are likely to overlap more within niches than across them. For example, producers of grass-fed beef have different cultural codes, sets of meanings, practices, organizational forms, etc., than do large industrial beef producers (Weber, Heinz, \& DeSoucey, 2008), though considerable terminology, practices, regulations etc., will still be common across niches. Similarly, Greenwood et al. (2002) describe three sub-communities within the accounting profession in Canada, and note that they serve different markets and have somewhat different interests, though they share professional standards.
} 
exchange fields, the shared objective of the field is to stabilize and coordinate exchange,

membership in networks and compatible practices (Beckert, 2010). The majority of field studies focus on a focal population, regarded as competitors for resources, status, market share and mindshare among their exchange partners.

Exchange fields can be further subtyped by the nature of the focal population within the field. We describe industry, professional and social movement exchange fields (see Table 1). While we acknowledge that there are other types of fields, such as state fields, or mixed fields involving, say, professions and an industry (e.g., doctors and health care organizations), for illustrative purposes, we limit our analysis to these three types of exchange fields.

Industry exchange fields ${ }^{5}$, such as the soft drink industry mentioned above, are focused on coordinating exchange among interaction partners, though members often collaborate to manage shared interests, such as lobbying or industry promotion, or to coordinate their interfaces with their common exchange partners by developing, for example, common technology or practice standards or coordinated labor relations. Garud, Jain and Kumaraswamy’s (2002) study of Sun's introduction of Java provides an example of both collaboration and competition among field members in the development of industry standards. Focal population members compete with one another over market share and legitimacy, and look to one another for best practices, technologies, industry recipes, etc. Boundaries in industry exchange fields tend to be relatively permeable to new entrants, though this will vary considerably by field (see Porter, 1980, for a discussion of barriers to entry).

Sometimes new entrants are able to introduce new ways of competing, contrary to dominant industry practice. They may transform industry practices, as new digital competitors

\footnotetext{
${ }^{5}$ We include non-commercial fields like museums (DiMaggio, 1991; Oakes, et al., 1998), symphony orchestras (Glynn, 2000; Glynn \& Lounsbury, 2005) and hospitals (Galvin, 2002) in this definition since we argue they contain structurally equivalent members that produce similar products/services, and their interaction partners.
} 
did with film-based photography (Munir, 2005), or as occurred with radio broadcasting (Leblebici, Salancik, Copay \& King, 1991), and on-line databases (Farjoun, 2002). Alternatively, some field members may form subfields around particular niches or strategic groups (Porac, Thomas \& Baden-Fuller, 1989), each of which may have its own identity and logic permutation. For example, Porac et al. (1989: 399), referred to firms defining themselves not only as part of the consumer electronics industry, but also as serving the high-end audiophile market, which determined their set of relationships (customers, suppliers, etc.) and the types of practices and structures they enacted. Similarly, Weber et al. (2008) described the separate identity, practices and exchange partners associated with grass-fed beef niche members versus the mainstream beef industry, and niches such as organic horticulture (Lepoutre \& Valente, 2012), rogue private schools (Quirke, 2013), and wind energy (Sine \& Lee, 2009) have also been described. While each logic permutation would have conflicting elements, the segmentation of the market allows each permutation to operate separately without much contradiction. Within each segment, a core/periphery structure will exist, usually based on the market share or reputation of organizations, and within the field as a whole, the dominant players in the dominant segments will be influential elites who may substantially exploit industry associations (Vermeulen, Buch \& Greenwood, 2007) or be asked to represent the industry by the state or other interaction partners (Hensmans, 2003).

The characteristics of industry populations have particular implications for institutional processes. In terms of isomorphism, since industry members are primarily focused on the legitimacy judgments of external audiences (e.g., customers, regulators, suppliers), isomorphic pressures are more likely to come from their exchange partners, and especially from those on whom actors are resource dependent (Freeman \& Audia, 2006; Pfeffer \& Salancik, 1978). These 
pressures will be shaped by what the external actors have come to expect from other industry members they observe within the strategic subgroup. Focal population members are likely to mimic most closely those organizations within their strategic groups, as these organizations face the same set of external actors, and are the focus for competitive analysis. Diffusion thus occurs within populations, often as a result of pressures from exchange partners such as insurance companies (Hoffman, 1999), consultants (Zbaracki, 1998) and regulators, but also with the training and encouragement of industry associations (van Wijk, Stam, Elfring, Zietsma, \& den Hond, 2013), other population members (Compagni, Mele, \& Ravasi, 2015), and with the aim of gaining legitimacy or technical advantages (Kennedy \& Fiss, 2009). Because of the competitive pressures in industry populations, we would expect new/superior practices, structures or technologies to emerge relatively frequently (e.g., Anand \& Peterson, 2000; Ansari \& Phillips, 2011; Gawer \& Phillips, 2013), and to diffuse relatively rapidly, especially within strategic groups. Industry members are likely to adapt innovations through diffusion to fit their own structures and markets, and innovate further to pursue competitive advantage through optimal distinctiveness (Deephouse, 1999).

Professional exchange fields feature a focal profession and its interaction partners, such as organizations in which professionals work, other professions they interface with, regulators, etc. For example, the professional exchange field of accounting includes accountants, accounting firms, the professional association, the regulator of the profession, educators of accounting professionals, etc. (Greenwood \& Suddaby, 2006). The purpose of professional exchange fields is to control professional practices and enforce boundaries around them. Professional populations often co-exist with industry populations in exchange fields, and whether the field is an industry exchange field or a professional exchange field depends on the focus of analysis. For example, 
studies have focused on doctors in the field of health care as an industry exchange field (Reay \& Hinings, 2005; 2009), or health care organizations in the professional exchange field of nursing (Reay, et al., 2006). Professional exchange fields usually contain professional organizations that, as gatekeepers, police membership and practice boundaries in the profession, socialize members and educate them regarding the set of practices to which they must adhere, creating strong identities. Thus they are strong structuring and constraining forces in the fields in which they exist (Adler \& Kwon, 2013; Suddaby \& Muzio, 2015). As a result, professional exchange fields have a high degree of homogeneity in practices and meanings, though there are established status hierarchies and niches of practice focus.

Because of the strong control over practices and norms, professional exchange fields are characterized by a single logic or a few relatively minor permutations. Areas of jurisdiction are often the subject of contestation among professions (Abbott, 1988; Bucher, Chreim, Langley, \& Reay, forthcoming). Within a professional exchange field, core organizations often shape the outlook of professionals and their career options, such as the Big Five accounting firms (Greenwood et al., 2002). As a result of these characteristics, isomorphism is strong and is reinforced through the professional association and professional educational and accreditation programs. Because of the relatively strong practice homogeneity within professional fields, we would expect innovations to be rarer than in industry fields, and to encounter more resistance to adoption, as studies of accounting (Greenwood et al., 2002; Suddaby \& Greenwood, 2005), law (Smets, Morris, \& Greenwood, 2012), and medical professional fields (Reay et al., 2006), suggest, particularly when they involve boundary disputes between professions (Bucher et al., forthcoming; Suddaby \& Greenwood, 2005). Once an innovation is endorsed by the professional association, however, we would expect diffusion to be rapid (Smets et al., 2012), though Colyvas 
and Jonsson (2011) remind us that diffusion and institutionalization are not the same thing, and a practice, like patenting by academics, may be endorsed but not widely diffused.

Social movement exchange fields (Curtis \& Zurcher, 1973; McCarthy \& Zald, 1977) exist to mobilize and coordinate actors and resources to further a specific agenda or extend an ideology, and members' identity connection to the population is related to their ideological commitment. They include movement organizations, funders, corporate partners, allied movements, etc. For example, the 'Slow Food' social movement exchange field includes gastronomes, farmers, food producers, food critics, social justice advocates, environmentalists, a foundation for biodiversity, a university of gastronomic sciences and other actors (van Bommel \& Spicer, 2013). While their overall identities vary, each identifies with the ideology of the Slow Food movement. Boundaries are quite permeable, as the intent is often to mobilize as many actors as possible in order to further the movement's agenda, and indeed, crossing boundaries into other fields is often a prime objective of movements (discussed below under issue fields). Social movement fields are characterized by emergent organizational collaboration and have as a consequence a quite limited institutional infrastructure (defined by Hinings, Logue, \& Zietsma, forthcoming as the set of institutions, usually mutually reinforcing, that guide field processes), compared to industry and professional exchange fields. In such fields, hierarchy is perceived to be limited, practices vary significantly (Bertels, Hoffman \& DeJordy, 2014), and governance is usually informal. Coordination among social movement organizations occurs through informal networks, with clusters of linked organizations, connected by "conduits" (organizations that bridge disconnected challenger groups), and "portals" (organizations that connect other challengers to corporate and other interaction partners) (Bertels et al., 2014). Relatedly, Diani and Bison (2004) differentiated between movement members who do not engage in networking, 
those who network intensely but do not define field identity and boundaries ("coalitional") and those who engage in multiplex relations and activities such as defining targets for the movement (“social movement organizations").

In social movement fields, isomorphism is focused mainly on adherence to ideology rather than practices, and members discipline themselves (and each other) with a desire to maintain both their social bonds (Creed et al., 2014) and the values they are emotionally invested in (Friedland, 2014; Gehman et al., 2013; Voronov \& Vince, 2012). Because such fields feature limited hierarchy and governance, we would expect diffusion of new practices to be spotty and feature significant variation. The social movement literature has recently noted the similarity of social movement fields to other fields, suggesting a larger role for organizations and processes of stratification of power relations similar to other exchange fields (Diani \& Bison, 2004; Duffy, Binder \& Skrentny, 2010). In related terms, other authors have viewed social movement fields as constituting a social movement sector where movement organization networks coalesce to build coalitions based on a variety of issues (Jung, King \& Soule, 2014).

Insert Table 1 about here

Issue fields. Hoffman (1999) and Wooten and Hoffman (2008) have championed the idea that fields form around issues rather than exchange relationships, and that fields can be analytically identified by the set of actors that interact and take one another into account on particular issues. Our approach to reviewing the research consistent with this view versus others is that the idea of issue fields is very fruitful for institutional analysis, but that such fields are distinct from exchange fields, and should be considered differently, because they have different effects on institutional processes. The purpose or focus of orchestration of issue fields is to negotiate, govern and/or compete over meanings and practices that affect multiple fields. Issue 
fields typically contain the most diverse set of actors, usually including populations with distinct identities and their own commitments to their own institutional infrastructure that may be located in different exchange fields. As the focal interest is an issue that carries different meanings to different populations, multiple and conflicting logics may be more the norm than the exception. As a result, issue-based fields are more "contested and dynamic in contrast to the settled character commonly ascribed to organizational fields (Wooten \& Hoffman, 2008)" (O’Sullivan \& Dwyer, 2015: 36), though they may become settled. We identify three subtypes of issue fields: competitive issue fields, interstitial issue fields and bridging issue fields.

Competitive issue fields. The most frequently studied way that issue fields arise is when one field or group of actors attempts to change the meanings and practices in an existing exchange field, such as when a social movement organization attempts to change an industry. Thus, two or more populations compete for dominance in such fields, often with dense interactions and homogeneous logics and identities within populations, and heterogeneous logics and identities, and conflictual interactions (sometimes through third parties such as the courts, customers or media) between populations. For example, Hoffman (1999) originally developed the idea of issue fields by studying the chemical industry, which was challenged by environmentalists seeking to make industry practices more sustainable. In the terms we have laid out above, the chemical industry was an industry exchange field that included suppliers, customers, insurers, consultants, regulators and others. When environmentalists (a social movement population) sought to challenge the industry population's environmental performance, an issue field was created. Note that the issue field did not concern the chemical industry's human resource practices, financial structures or distribution channels - these remained in the exchange field. Instead, the issue field focused on environmental management. Yet it did include 
the chemical industry exchange fields' other members, as social movement activists sought to influence regulators, attack chemical firms through the courts and influence customers. Indeed, the use of environmental management systems in response to the environmental pressures was diffused by insurance providers (seeking to reduce their risk of lawsuits) and consultants (seeking business), both interaction partners for the exchange field. Thus the exchange field is in play when an issue field emerges.

A common strategy for social movements is to exert influence with powerful members of the exchange field such as customers or regulators, who can then exert influence on focal industry or professional populations (Gurses \& Ozcan, 2015; Holm, 1995). This is a means by which social movement organizations can gain access to the boundaries around decision making in the exchange field (Zietsma \& Lawrence, 2010), challenging jurisdictions and practices. However, the issue field concerns a more limited set of meanings and practices, and features competing logics applying to the same bounded space. Individual populations within the issue field with differentiated identities will face isomorphic pressures to adhere to their group's own institutions, along with competing pressures from other populations and allied interaction partners in the issue field. Issue fields not only concern industries and social movements but also boundary disputes among professions, such as reallocation of responsibilities in medical fields (Bucher et al., forthcoming; Dunn \& Jones, 2010; Goodrick \& Reay, 2011; Reay \& Hinings, 2005; 2009), or the boundaries between legal and accounting firms (Suddaby \& Greenwood, 2005); and between professions and industry, such as between scientists and pharmaceutical companies (Murray, 2010), and between law firms and a legal professional association (Smets et al., 2012).

O'Sullivan and O'Dwyer (2015: 35) studied the issue field regarding social 
accountability of project finance, and argued that powerful mature (exchange) field incumbents are more likely to "capture" the issue, and lead in developing institutional infrastructure that fits with their existing logics, because it is they "who possess the necessary resources to develop issue-based institutions and practices", though van Wijk et al. (2013) noted that co-optation was mutual in an issue field for sustainable tourism. In the O'Sullivan and O'Dwyer (2015) study, the Equator Principles for responsible finance were designed by the industry to suit them, and these authors argued that such issue-based fields are "subordinate to the more authoritative mature field (see, Fligstein \& McAdam, 2011), certainly in the initial stages of issue-based field structuration” (O’Sullivan and O’Dwyer, 2015: 49), yet issue and exchange fields develop a mutual dependency as the issue and its institutional infrastructure become assimilated into the exchange field over time. Indeed, since the modus operandi of many social movement organizations is to campaign until reasonable change in fields has been made, and then to move on to higher priority issues, competitive issue fields themselves may be temporary structures for integrating new societal concerns into the infrastructure of exchange fields. Because of the contested and in-flux nature of competitive issue fields, isomorphism and diffusion pressures are likely to be contradictory until settlements that encompass the interests of key populations are reached.

Interstitial issue fields. Interstitial positions are structural positions between or at the overlap of institutional fields (Rao, Morrill, \& Zald, 2000), wherein members of different fields interact with one another (Furnari, 2014), because they share a common interest or issue. While they have been described in the literature quite separately, there is a case to be made for considering organizing efforts in interstitial spaces to be issue fields. Interstitial issue fields are fields that arise in these interstitial locations, drawing members from multiple fields and logics, 
with the purpose of negotiating coordination to respond to emerging issues or opportunities. An interstitial issue field may emerge when an issue arises in society that people care about across several (and sometimes a broad spectrum of) social groups. For example, concerns about HIV/AIDS (Maguire, Hardy, \& Lawrence, 2004), poverty alleviation, the Zika virus, climate change and income inequality are all issues that concern members of multiple fields. Such issues can come from exogenous shocks (e.g., Zika virus), the gradual buildup of awareness of collective problems (e.g., HIV/AIDS) or opportunities (e.g., home computers, Furnari, 2014; biotechnology, Powell \& Sandholtz, 2012) or the reframing of issues by social movements or others (e.g., income inequality). Medvetz (2012) gave the example of think tanks in the U.S. as actors occupying stable interstitial positions weaving together different fields (academic, political, business, media production), while maintaining a separate identity. Because members of the interstitial issue field come from multiple exchange fields and civil society, no one field is likely to dominate discussions on the issue, logics are multiple and fragmented, and boundaries are permeable. Over time and through negotiations, disparate groups form alliances, and shared identity and field infrastructures may emerge.

Interstitial issue fields often form their infrastructures by combining elements drawn from the fields from which their members come. For example, the impact investing field draws elements of its institutional infrastructure from existing exchange fields including investment, corporate social responsibility, social enterprise, government, NGOs and social movement fields, though sometimes these elements are competing, and their use is not yet institutionalized (Hinings, Logue, \& Zietsma, forthcoming). Similarly, Powell and Sandholtz (2012) argued that the founders of new biotechnology firms borrowed elements from different external fields to construct their ventures. Because these fields are often fragmented during their emergence, 
isomorphic pressures are weak, and a field identity is ambiguous and emerging. Boundaries are highly permeable. Diffusion is uncertain.

Importantly, though, once institutional infrastructure becomes stabilized within an issue field, there is little to distinguish it from an exchange field, and we could conceive of the issue field as becoming an exchange field over time. For example, Furnari (2014) described the Homebrew Computer Club as an interstitial space where people from multiple fields interacted on the issue of home computers, planting the seeds for the personal computer industry exchange field of today; Akemu, Whiteman and Kennedy (2016) show how the Fairphone exchange field emerged from social activism and the creation of an issue field; and Granqvist and Laurila (2011) described how industry, science, government and environmentalists organized around the issue of nanotechnology, which eventually became an industry exchange field of its own. While the borrowing and blending that occurs in interstitial positions may resemble that done by hybrid organizations (Battilana \& Lee, 2014), on balance this work suggests that organizations in interstitial positions may be part of emerging interstitial fields, which are likely to become exchange fields over time as institutional infrastructure becomes more elaborated.

Bridging issue fields exist when issues are inherently cross-jurisdictional and will remain so over time, such as the governance of common resources or shared issues. For example, corporate social responsibility is a multiplex issue that concerns many different fields and logics. Transnational governance organizations such as labor and corporate social responsibility standards organizations (Helfen \& Sydow, 2013; Helms, Oliver, \& Webb, 2012), often act as boundary organizations that connect multiple fields on particular issues. A simpler example concerns the boundary organization that governs the interactions between the open source software movement and the software industry (O’Mahony \& Bechky, 2008). In bridging issue 
fields, representatives of two or more interacting fields or groups will comprise the field, frequently along with an agreed upon or formally appointed boundary organization (O’Mahony \& Bechky, 2008), to focus on the issue, bridge diverse groups and coordinate issue-related activity across multiple fields, such as is the case with ISO and its 26000 standard (Helms, Oliver, \& Webb, 2012), or multiple geographies in transnational policy fields (Schüssler, Rüling \& Wittneben, 2014). Boundaries tend to be formalized and often managed by the boundary organization. Identities are heterogeneous. Through the governance of the boundary organization or agreement, settled bridging fields will feature blended logics around the issue, even if the constituents' logics in general are contradictory. Isomorphic pressures come from the governance organization or the normative force of a constituents' agreement, and as result, when innovations occur that affect the issue, they are not likely to diffuse broadly until constituents come to agreements, enforced by the governance organization. In contrast to more temporary competitive and interstitial issue fields, bridging issue fields may be long lasting.

Overall, then, we would expect to see more change in issue fields relative to exchange fields, though the change target may in fact be an exchange field. We would also expect many issue fields to be more temporary than exchange fields, with the exception of bridging issue fields. Change processes in fields will also depend on field conditions, however, as described in the next section.

\section{Field Conditions}

Fields vary in their degree of institutionalization, their evolutionary stage and their complexity, and a number of terms have been used in the literature to describe such field conditions. These conditions influence the number and nature of institutional demands affecting organizations in a field (Greenwood et al., 2011) and are important influencers of institutional 
processes. Fields have been described as highly institutionalized or structured (Gomez \& Bouty, 2011; Greenwood et al., 2002; Vaccaro \& Palazzo, 2015), established (Purdy \& Gray, 2009), mature (Greenwood \& Suddaby, 2006), hierarchical (Rao et al., 2000), emerging (Maguire et al., 2004), nascent (Patvardhan, Gioia \& Hamilton, 2015), turbulent (Farjoun, 2002), fragmented (Meyer, Scott \& Strang, 1987), complex (Reay \& Hinings, 2009), patchy (Quirke, 2013), or contested (Hensmans, 2003; Meyer \& Höllerer, 2010). Highly institutionalized, or structured, fields feature "relatively well-structured configurations of actors that are aware of their involvement in a common enterprise and among which there are identifiable patterns of interaction", and in which "membership [is] clearly defined; institutions [are] highly legitimated; and relationships among actors [are] also clearly defined" (Maguire et al., 2004: 658-9). Logics are coherent or ordered in these fields.

Highly institutionalized fields have been characterized as having a highly elaborated institutional infrastructure, with thick, overlapping and self-reinforcing sets of institutions (Hinings, Logue \& Zietsma, forthcoming). Such fields have been labeled as "mature fields" (Greenwood et al., 2002), or "settled" or "stable" fields (Fligstein, 1997). In highly institutionalized fields, there is a "distinct dominance order in which a few groups of actors operate at the apex while others survive on the bottom. In such instances, groups of influential actors have vested interests in preserving the social order" (Rao et al., 2000: 262).

In contrast to mature or highly institutionalized fields, emerging fields are described as “underorganized domains" where "members recognize some degree of mutual interest”, but "relatively little coordinated action exists among them" (Maguire et al., 2004: 659). Networks and proto-institutions (Lawrence, Hardy \& Phillips, 2002) are provisional—-"narrowly diffused and weakly entrenched" (Maguire et al., 2004: 659). Interested actors may come from different 
fields, such as non-governmental development organizations and for-profit financial firms in microfinance. As such, such actors will be embedded in different institutional logics and are likely to translate elements of their particular institutional infrastructure with them in emerging fields.

Yet emerging and mature both refer to a lifecycle stage of institutional fields, rather than the conditions of a field. Prior studies suggest that both emerging and mature fields may feature different field conditions. While it is suggested that all emerging fields will have weak or sparsely elaborated institutional infrastructure, some of these fields have been shown to exhibit alignment or broad agreement among field members as to what that infrastructure is or should be, while others have fragmented and competing understandings. For example, Garud and Karnoe (2001: 11) describe how when "constituent elements of a technological field begin working with one another, they become 'aligned' and begin reinforcing one another. Meanings of objects constituting these fields emerge through a process of negotiation and provisionally stabilize." The emergence of the industry exchange field of information schools in the U.S. and Canada was associated with an orchestrated and coherent iSchools Movement identity campaign, showing alignment at emergence. However, as the field expanded with "loose membership criteria" (Patvardhan et al., 2015: 418), and new members brought their own identity elements from their other institutional contexts, the collective identity of the field began to fragment and diverge, leading to a crisis.

Other emerging fields are more fragmented from the beginning, however, as subgroups exist and have different conceptions about appropriate proto-institutions, such as the interstitial issue field of HIV/AIDS treatment (Maguire et al., 2004), drawing members from pharmaceutical companies, activist organizations and medical organizations. Similarly, while 
some authors describe stable fields as mature, it is also clear that mature fields may vary in the extent to which logics are settled and institutional infrastructure is elaborated. In our review of the literature, we note that many mature fields become disrupted or contested, and they may contain multiple and competing logics (see, e.g., Leblebici et al., 1991). Researchers should thus avoid confusing field conditions with lifecycle stage and treat these two ideas separately.

Typology of field conditions. We categorize the field conditions identified by others into a parsimonious typology classified by the state of institutional infrastructure (limited or highly elaborated), and the extent to which different logics and networks within the field are in a settled versus an unsettled prioritization (see Table 2). Fields with a highly elaborated institutional infrastructure, consisting of meanings, practices, identities, power structures, subject positions and governance mechanisms (Hinings et al., forthcoming), will feature relatively clear conceptions about what is appropriate or allowed in most situations. Infrastructure elements will tend to reinforce one another, providing relatively unambiguous and often taken-for-granted guidelines about appropriate action via both formal and informal mechanisms. In fields with limited institutional infrastructure, networks, rules, identities, practices, meanings and governance mechanisms may be ambiguous, unelaborated, provisional, subject to reflexive debate rather than being taken for granted, and mutually reinforcing. Yet with either limited or elaborated institutional infrastructure, we must also consider the extent to which logics and power are settled or unsettled within a field.

Raynard (forthcoming) argued that the kind of complexity that exists in an institutional field depends on the degree to which there are incompatibilities and jurisdictional overlaps among logics, and the prioritization of logics is settled. We combine the factors of logic prioritization and jurisdictional overlaps by considering the extent to which there is a settled 
prioritization of logics in fields across domains. This factor refers to the possibility that there may be one logic that all subscribe to, multiple logics that are complementary, or multiple logics that are compartmentalized in different domains, differentially affecting diverse groups of actors within fields, yet with a clear understanding among field members as to which logic has priority within any given domain (Goodrick \& Reay, 2011; Reay \& Hinings, 2009). For example, Goodrick and Reay (2011) identified professional, corporate, market and state logics that influenced the field of pharmacy in mostly complementary and segmented ways, though the constellation of these logics varied by historical era. Studies on medical professional boundary negotiations illustrate that the logic prioritization in the healthcare field is well established and understood (doctors, nurses, nurses' assistants, psychologists, psychological assistants, etc.), varying by practice domain (e.g., psychological vs. medical, surgical vs. bedside care), even though negotiations might take place at the margins (Bucher et al., forthcoming).

Notably, when logic prioritizations are settled, but there is limited institutional infrastructure, there may be alignment among actors on general principles and values. Alignment is stabilizing (Levy \& Scully, 2007). Yet, there may be less understanding of how to put those principles and values into practice, and few unambiguous norms, rules or governance systems that enable consistent action. We say these fields are aligned or aligning, since field participants have aligned objectives and values, with the recognition that such fields can fall out of alignment, and often do, when the ambiguity in practices, rules and norms results in disagreements about the appropriateness of various actions (Patvardhan et al., 2015).

When instead the field features settled logic prioritizations and elaborated institutional infrastructure, consistent with Purdy and Gray (2009), we refer to its condition as established, since field members know what to expect from each other, and within any given action domain 
within the field, there is a clear set of mutually-reinforcing institutional arrangements that guide behavior. This is not to say that established fields will not change: in fact, much of the institutional change literature starts with a description of a stable field that later changed because of the rise of new actors, new interests or exogenous shocks that changed power positions or unsettled logic prioritizations (Borum, 2004; Greenwood et al., 2002; Hoffman, 1999; Sauder, 2008; Vaccaro \& Palazzo, 2015).

Fields with unsettled logic prioritizations either do not have accepted networks and logics, or they have contested logic and power prioritizations, with contradicting or incompatible claims in the same domains. Raynard (forthcoming) refers to such domains as featuring volatile institutional complexity, and they have been referred to in the literature by others as being contested (Hardy \& Maguire, 2010; van Gestel \& Hillebrand, 2011) or turbulent (Farjoun, 2002). When unsettled logic prioritizations are combined with elaborated institutional infrastructure, and in line with the majority of studies that have described such fields, we refer to field conditions as contested. We note that what is contested goes beyond competing logics. It includes power relations associated with which actors have dominance in particular practice domains, and which rule systems should dominate-and perspectives on these typically differ among networks of actors, such that institutional infrastructure is elaborated differently within different network clusters.

On the other hand, we describe fields with unsettled logic prioritizations and limited institutional infrastructure as fragmented, consistent with other descriptions of such fields in the literature. Fragmented fields have not coalesced - disconnected actors or small groups may be focused on a particular issue, but they have not established networks or institutions that prescribe a particular way of interpreting or enacting the issue, or those networks have broken apart as 
disagreements on practices occurred. Fields may be fragmented if they emerge in interstitial positions, drawing logics and practices from different adjacent fields (Powell \& Sandholtz, 2012), or because new actors with new ideas enter a field with different ideas about appropriate action (Patvardhan et al., 2015). Table 2 shows the field conditions we have described.

Insert Table 2 about here

\section{Agency and Fields}

We have described various field types and conditions, and in this section, our review of the literature shows that these factors have significant impact on the agency that is possible for various actors within the field. This speaks to the paradox of embedded agency (Holm, 1995), a key issue in institutional theory, focusing on the problem of how those embedded in institutions are able to become disembedded enough to try to change them. Many of the early studies of agency in institutional fields took an institutional entrepreneurship perspective, focusing on individuals or organizations that attempt to change institutions (see Battilana, Leca, \& Boxenbaum, 2009, for a review). This approach has been criticized for presenting an image of agency that is not only unconstrained by institutional pressures, i.e., that is disembedded (Cooper, Ezzamel \& Willmott, 2008; Delmestri, 2006), but that is also single-handedly able to disembed others — a "hypermuscular", heroic actor (Lawrence, Suddaby, \& Leca, 2009).

Yet Battilana et al. (2009) argued that embeddedness is always central to institutional agency: institutional entrepreneurs always act in context. These authors describe the importance of a number of factors that influence agency in institutional fields. Exogenous shocks (Child et al., 2007; Hoffman, 1999; Holm, 1995), including social, technological or regulatory changes (Greenwood et al., 2002), political crises (Fligstein \& Mara-Drita, 1996) or natural disasters and environmental issues (Phillips, Lawrence, \& Hardy, 2000) have all been identified as triggers 
that disrupt a field sufficiently to enable an institutional entrepreneur to reinterpret the environment to support their change project (Beckert, 1999). Others suggest that fields featuring institutional contradictions (Seo \& Creed, 2002), or institutional complexity (Clemens \& Cook, 1999; Greenwood et al., 2011) enable reflexivity and thus at least partially disembedded action. In addition, fields that are emerging (Maguire et al., 2004) or otherwise weakly institutionalized (Fligstein, 1997; Garud et al., 2002; Sewell, 1992), feature weak constraints, providing greater latitude for action. On the other hand, some authors suggest that the strategic agency of institutional entrepreneurship may be better enabled by strongly institutionalized fields where there is more certainty (Dorado, 2005), and some studies clearly show that institutional entrepreneurship occurs in mature fields (Greenwood et al., 2002), although sometimes the field remains stagnant (Marcus \& Anderson, 2010).

Yet incumbents in mature fields are likely to have the power and incentives to maintain field arrangements, while peripheral actors who may be least embedded, and may have the incentive to change institutional arrangements, may not have the influence to do so (Fligstein, 2001). Literature on institutional work has arisen attempting to show a more embedded view of agency involving not just the creation or disruption of institutions, but also the maintenance of institutions, as actors struggle and compete to change or stabilize institutional fields under various field conditions (Lawrence \& Suddaby, 2006; Lawrence et al., 2009; Maguire \& Hardy, 2009). Thus, exogenous triggers may provide an opportunity for agency, as field actors translate or interpret changes in societal logics (Briscoe \& Safford, 2008; Hensmans, 2003), state rules (Orsato, den Hond \& Clegg, 2002; Purdy \& Gray, 2009), peripheral or adjacent fields (Mazza \& Pedersen, 2004; Meyer \& Höllerer, 2010; Zilber, 2007), or technology changes (Munir, 2005). Yet agency in institutional fields will be significantly affected by actors' subject positions, and 
by field conditions. We review what we know about actors' field positions and their opportunities for agency and then describe the influence of field conditions.

Actors' subject positions and agency. Extant literature suggests that within fields, not all actors have equivalent influence on field processes such as maintaining the status quo and keeping boundaries in place. Underlying these processes are different mechanisms that ensure or endanger positions of actors in a field. As such, the following forces are notable in the literature: (1) status differences and core/periphery structure, which suggests both hierarchy and network imagery of fields, and (2) the existence of actors that play structuring or governing roles, such as professional associations, accreditation, standards or governance organizations and organizers of awards, ceremonies or other field-configuring events. While we review what is known about subject positions and agency, we also bring nuance to this discussion, referring to our analysis of exchange and issue fields, with the following insights: First, while in exchange fields, it may be clear who central/elite and peripheral actors are, and who is responsible for governance, in issue fields, which bring together constituents from two or more disparate fields, field positions are in flux. What we know about embeddedness has to be reconsidered to take into consideration that field members will be embedded in different populations within issue fields that likely do not share opinions on status hierarchies. Competitions over issues may well not only make power and status contested in issue fields, but they may also disrupt power and status in affiliated exchange fields. Furthermore, even within exchange fields, when field conditions are contested, realigning or fragmented, status hierarchies are less clear and opportunities to influence field processes are likely more open to all actors-further research is needed to identify the limits of what we know about field positions.

Central/elite Actors. High-status central or elite actors may have significant influence on 
both change and stability within exchange fields (Brint \& Karabel, 1991). For example, Greenwood and colleagues found that elite accounting firms (Greenwood et al., 2002);

Greenwood \& Suddaby, 2006) and law firms (Smets et al., 2012) were the architects of changes in their field, which professional associations eventually adopted. Elite actors tend to span boundaries to other fields, and thus they have more awareness of alternatives (Greenwood et al., 2002) and the influence within the field to convince others to change with them. Gawer and Phillips (2013) showed how Intel was able to shape the developmental trajectory in the field of semiconductors. A study of French cancer research centers found that a group of elite reformers changed the operations in this field (Castel \& Friedberg, 2010). Yet central and elite actors are often the actors defending the status quo arrangements that privilege them. For example, Maguire and Hardy (2008) document how elite incumbents engaged in defensive institutional work to continue using DDT; Hensmans (2003) documented how the Recording Industry Association fought Napster's peer sharing model; and Smets et al. (2012) documented how the German legal professional association fought changes in contract language advanced by a lead firm working across borders. Our review of the studies suggests that elite/central actors are more likely to initiate change in exchange fields by introducing innovations that respond to technological, social or market changes in such a way as to reinforce or augment their privileged position within the normal rules of the game (Ansari \& Phillips, 2011; Garud et al., 2002; Gawer \& Phillips, 2013). Elite/central actors typically resist change in issue fields where disputes threaten the rules of the game and the distribution of power is at risk (Hensmans, 2003; Orsato et al., 2002; Reay \& Hinings, 2005; Vaccaro \& Palazzo, 2015; Vermeulen et al., 2007). Furthermore, the benefits of being a central actor in an exchange field may well become liabilities in a competitive issue field, since central/elite actors make excellent targets for social 
movement campaigns (Meznar \& Nigh, 1995). Social movement organizations’ efforts to discredit central/elite actors may mean these actors are more constrained than they are in exchange fields.

Peripheral or marginalized actors. Peripheral or marginalized actors may be less bound by institutional prescriptions compared to central and well-connected actors (Leblebici et al., 1991; Maguire et al., 2004; Rao et al., 2000) and thus are more likely to introduce innovations, as Quirke (2013) identified among Toronto private schools, where some schools may be "rogue". The issue for peripheral actors is whether or not they have the resources or capacity to compete for status or market position. In exchange fields, when peripheral actors introduce new technologies or business models, they may be successful in changing an industry (Leblebici et al., 1991; Munir, 2005), though they are likely to prompt competitive retaliation, and they are sometimes acquired by elite actors in an attempt to preserve those actors' power positions (Anand \& Peterson, 2000; Hensmans, 2003). On the other hand, peripheral actors pursuing niche positions may "fly under the radar" (Leung, Zietsma, \& Peredo, 2014), seeming to have symbolic and material immunity (Lepoutre \& Valente, 2012) in these niche positions, as long as the niches remain small and unthreatening (Ingenbleek \& Reinders, 2013; Quirke, 2013). In issue fields, which peripheral actors may create by raising a grievance, these actors usually do not accept the legitimacy of the rules and governance mechanisms that dominate in the field. They may attempt to influence powerful actors that are at the societal level, such as the courts (Hoffman, 1999) or the state (Vermeulen et al., 2007; Holm, 1995), or they may forge coalitions among peripheral subfields (Fligstein \& McAdam, 2012; Helfen, 2015; van Bommel \& Spicer, 2011), or gain the support of more powerful field members or powerful actors from other fields (including adjacent, higher-order societal or transnational fields, Helfen, 2015), in order to 
increase their influence. For example, Holm (1995) showed how Norwegian fisherman and merchants competed over political support to increase their influence and ability to extract resources from their field. On the other hand, peripheral actors may work with or co-opt central or elite actors to attempt to change the field (van Wijk et al., 2013; Helfen, 2015).

Middle status actors. In recent publications, middle status actors have come into view as defenders of the status hierarchy in professional fields. For instance, implementation of externally demanded changes that threatened to upset the hierarchy in hospitals was shown to be most vehemently opposed by middle status professionals (Kellogg, 2009). On the other hand, Bucher et al. (forthcoming), found in a study of medical professionals that higher status and middle status actors defended professional boundaries against those with lower status, but lower and middle status actors also sought to change boundaries to allow their own group more professional autonomy relative to those above them. Wright and Zammuto (2013) show how middle status actors sought change in the field of English cricket, developing it from an elite sport to a broader business-based sport. Thus given that middle status actors potentially compete both above and below their own status, it is likely that they will defend rules that protect their position and attempt to innovate where they have an opportunity to improve their position. Only limited work has examined this idea; therefore, it is not possible to develop more general conclusions with confidence, but it may be that middle status actors will be more likely to defend the status quo in issue fields where their position is threatened, and more likely to innovate in exchange fields where they have an opportunity to increase their share of the rewards associated with status quo arrangements.

New actors. A dynamic view of fields also construes that it is not only positional differences that play a role but also that new actors can enter the field over time, increasing 
diversity not only in constituents but also in their preferred goals and means. New actors come with the rise of new issues in society, such as the rise of the environmental logic in multiple sectors such as the chemical field (Hoffman, 1999; Maguire \& Hardy, 2009), or the rise of new technologies or practices, which may disrupt field power positions (Munir \& Phillips, 2005; Leblebici et al., 1991; Farjoun, 2002). Many of the studies we reviewed began by discussing new actors entering the field. For example, in the information schools field (Patvardhan et al., 2015), the expansion of membership in the field led to a fragmentation and contestation of identity. Multiply embedded actors. We have already referred to the importance of boundary spanning or bridging ties as a means of making elite actors aware of more alternatives (Greenwood et al., 2002). Boundary spanners are embedded in one field but are connected to others through network ties. While boundary spanning has impacts on the reflexivity of those who connect to other fields, boundary spanners are not necessarily embedded in multiple fields. Some actors are embedded in multiple fields, however, and this multiple embeddedness can contribute to their reflexivity and/or it can exert counter pressures on them, creating deviation from dominant templates in any given field. For example, Greenwood, Diaz, Li and Lorente (2010) showed how firms responded to market pressures to downsize in divergent ways because of their embeddedness in regional state and family logics. A range of papers has also now identified the importance of community logics in affecting actors (Lee \& Lounsbury, 2015; Lounsbury, 2007; Marquis \& Lounsbury, 2008). Perhaps the majority of work on this concept comes from the international business literature, focusing on the opportunities and constraints on action afforded to MNEs by virtue of their subsidiary's embeddedness in multiple country contexts, as well as the internal network of the MNE itself (Ferraris, 2014; Meyer, Mudambi, \& Narula, 2011). There has also been an explosion of work on hybrid organizations, which 
suggests that there are many actors who are embedded in more than one logic (Battilana \& Dorado, 2010; Battilana \& Lee, 2014; Jay, 2013; Pache \& Santos, 2010). While the emphasis on logics tends to obscure the influence of fields, in fact many of these actors are simultaneously involved in more than one field (such as a community and an industry, Lounsbury, 2007), or at least in an interstitial position between different fields, which may be more descriptive of hybrid organizations. In addition, fields and field actors are also embedded in societal spheres, which may be influential by geography, by religion or social group or even by technology, as the idea of the "digital age" suggests. This multiple embeddedness is simultaneously a source of innovation (as members bring new material in) and a source of constraints on action.

Field-structuring or governing organizations. A number of organizations have a significant influence on structuring or governing institutional fields. These include (1) formal governance units, such as regulators, industry standards and certifiers, (2) arbiters of taste, such as awards, charts or ratings, and (3) field coordinators such as industry/professional associations, or organizers of field-configuring events such as conferences or negotiations.

Formal governance units. Formal governance units may either be external to the field, sometimes national or transnational, such as a state government, ISO 26000 (Helms et al., 2012), or international labor organizations (Helfen \& Sydow, 2013), or internal to the field, such as a field's regulator, or a field-specific voluntary governance body. Introducing new environmental regulations in China was undertaken by newly founded organizations that ordered multiple fields (Child et al., 2007). In the creation of the Czech and Hungarian banking sector interventions by regulators, negotiating with the banks established rules for this sector (Tihanyi \& Hegarty 2007). Government might also be involved in empowering certain groups, such as clusters of researchers and industry in the semiconductor field (Sydow, Windeler, Schubert, \& Mollering, 
2012), or in negotiating transnational agreements that govern multiple fields (Evans \& Kay, 2008; Helfen \& Sydow, 2013). Government regulators are considered within the field by the definition of DiMaggio and Powell (1983), but many cross fields as well, and they themselves belong to a societal field of regulators, reporting to the state, and subject to isomorphic influences within the field of regulators.

Many voluntary governance units also exist, including ISO 26000 and 14001, Forest Stewardship Council (Bartley, 2007), Fair Trade (Ingenbleek \& Reinders, 2013; Reinecke, Manning \& von Hagen, 2012), Organic (Lepoutre \& Valente, 2012), etc., often negotiated by members. These voluntary mechanisms may cover small niches, or they may be more broadly applicable to whole populations or transnational arenas (Djelic \& Sahlin-Andersson, 2006). Voluntary governance mechanisms are used to address collective or societal issues, leveling the playing field by embedding practices into shared standards.

Arbiters of taste. Certain organizations play a significant role in structuring fields by acting as arbiters of taste. For example, Sauder (2008) described the significant effect that U.S. News had on law school education when it initiated its rankings. Similarly, when Soundscan developed a better technology for assessing popularity in the music industry than the marketorchestrating Billboard's charts, various genres gained or lost status in the field (Anand \& Peterson, 2000). Grammy Awards (Anand \& Watson, 2004) and literary prizes (Anand \& Jones, 2008) have been shown to have significant structuring effects on fields. Voronov, DeClerq and Hinings (2013) show how wine critics and restaurant owners are important in giving legitimacy to Ontario wine as part of the fine wine field.

Field coordinators. In addition to formal governance units and arbiters of taste, professional, trade or industry associations or movement leaders often play a significant role in 
structuring a field. They may organize field-configuring events (Glynn, 2008; Hardy \& Maguire, 2010; McInerney, 2008; Oliver \& Montgomery, 2008; Schüssler, et al., 2014), or they may develop field-specific standards to manage industry reputation, and then enforce adherence (Buchanan, 2016; van Wijk et al., 2013). Vermeulen et al. (2007) found that the Dutch concrete industry association exerted considerable influence over innovation potential, favoring incumbent positions versus new entrants. Trade associations often lobby regulators (Gurses \& Ozcan, 2015), develop industry positions on issues and maintain industry solidarity. They may work with government to organize field-configuring events. These governing units also influence the manner in which new practices and values are taken up in the field (Buchanan, 2016). Similarly, professional associations play a significant role in managing issues, enforcing professional standards, dealing with regulators and coordinating professional education and events (Smets et al., 2012; Greenwood \& Suddaby, 2006), and they act as both sources of stability and sources of change in institutional fields. It is important to note, however, that field structuring or governing organizations are differentially considered legitimate by different populations of actors within institutional fields. In established exchange fields, such organizations are likely to have significant influence, while in contested issue fields, there may be multiple field coordinators or arbiters competing over field structuring.

Agency and fields summary. Our review suggests that institutional fields, considering the types and conditions we have described, are significantly more heterogeneous than the work of early institutional theorists suggested. Given this heterogeneity, what is the source and power of isomorphism — who is embedded in what? Without a careful consideration of this point, we risk muting the explanatory power of institutional theory. If we consider fields to be made up of disparate groups of norms and ideas (issue fields), or the different practice sets associated with 
different populations and/or strategic subgroups (exchange fields), we lose the insight into what makes change difficult in practice. Indeed, the intense focus on institutional change in fields over the last decade or so risks throwing the isomorphic baby out with the bathwater, treating much action as if it were disembedded. And yet many studies continue to refer to the field as the site of a common set of norms that constrain behavior, thus continuing to refer to embeddedness in word, though less in practice.

A closer analysis of the type and conditions of institutional fields provides much more nuance associated with the understanding of agency and isomorphism within fields. For example, when logic prioritizations are not settled (as is the case in fragmented and contested fields), actors may be embedded in logics that come from different populations, or they may even bring logics from completely different fields, particularly in interstitial or other issue fields. With an understanding of the extent of elaboration of the infrastructure of the field, we can also determine just how constraining (or not) a field might be. With an understanding of populations and subfields, it is easier for the analyst to understand just what set of institutions any given actor is embedded within. Furthermore, knowing that multiple populations and subfields inhabit a field enables us to understand better the potential for contradictions within the field, which enable not only the reflexivity to question taken-for-granted institutions, but also the possibility for agency (Seo \& Creed, 2002). Our review thus suggests that attention to field types and conditions, in interaction with agency, can lead to institutional change or can prevent such change from happening. We turn now to an examination of institutional change.

\section{Fields and Change}

From our literature review of field types and conditions, change has become a constant and enduring dynamic. The often used lifecycle labels of 'emerging' and 'mature' restrict 
analysis to an evolutionary understanding of fields based on time passed (Wooten \& Hoffman, 2008). It is surprising then, given this lifecycle emphasis, that there are nearly no explicit studies on the demise of fields (although some work considers processes of deinstitutionalization, such as the work of Oliver, 1992). Indeed, studies of fields over longer periods of time are scarce (for exceptions see Galvin, 2002; Leblibici et al., 1991; Scott, Ruef, Mendel, \& Caronna, 2000; van Gestel \& Hillebrand, 2011), and we could learn from studies on strategic failure (Baumard \& Starbuck, 2005), and disappearing industries (Porac, Thomas, \& Baden-Fuller, 2011). The duration of a study impacts how observations of field conditions are made; whether a field is analyzed as established, contested or (re)established may significantly depend on the amount of time that has passed.

Within a lifecycle approach, there is also the assumption of a linear and irreversible progression (Van de Ven \& Poole, 1995) to an equilibrium. Neither the linearity (Amis, Slack, \& Hinings, 2004) nor equilibrium assumptions, which pervade social theory (Meyer et al., 2005), hold up to analysis, as many of the studies we reviewed showed established institutionalized fields reverting to contested or fragmented conditions, or realigning to accommodate new infrastructure to support changes in technology, organizational forms or practices. Reversals and oscillations seem to be more the norm than the exception (Amis et al., 2004), and returns to prior states may be possible as latent conditions resurface (Cardinal, Sitkin, \& Long, 2004).

Assumptions of a natural tendency toward equilibrium may lead analysts to see change and problems in fields in terms of equilibrium shifts - determining the truncation of their studies and common categorization of field state as "disrupted".

Scott (2014) has characterized the move from a primary concern with institutional stability to an increasing concern with institutional change as a mark of the maturation of 
institutional theory and research. But in spite of a greater concern with change, as evidenced by the more recent theorizations of institutional work (cf. Lawrence \& Suddaby, 2006), institutional entrepreneurship (cf. Maguire, Hardy, \& Lawrence, 2004), institutional complexity (Greenwood et al., 2012) and institutional logics (Thornton et al., 2012), as we have suggested, there is a lack of such theorization in studying field-level change holistically. What, then, do we suggest as a way forward in this important area?

First, we need to utilize ideas that have been developed on organizational change that are transferable to the field level. We start with the idea of 'periodicity' (Greenwood \& Hinings, 2006; Hinings \& Greenwood, 1988; Pettigrew, Woodman, \& Cameron, 2001), which combines three issues. If we wish to answer the question of how fields move from 'aligning' to 'established' or any other sequence of institutional change, we need to examine the scope of change, the pace of change, and the linearity of change (Amis et al., 2004).

The idea of scope draws attention to which elements change and how much changes. There is a commonality in all definitions of fields: that they are made up of actors in networks of relationship, with those relationships structured around common meanings and interests. An important question in understanding field-level change is which of these elements, actors, networks of relationships and meaning systems (logics) changes, and is there any order or sequence to that change? Work on institutional entrepreneurship suggests that much change occurs through new actors who bring different logics and relationships into the field (Maguire \& Hardy, 2009; Thornton et al., 2012). How does institutional change involve other kinds of actors, such as those concerned with governance and legitimation? What effect does institutional change have on hierarchies of status and influence and subsequent power relations? The point of these kinds of questions about field change is to draw attention to which elements change. 
Conceptualizing change requires careful specification of what changes that can only be done if there is similarly careful specification of the elements of a field.

There is little in the study of institutional change that deals with the pace of change, i.e., the speed at which a field moves from one state to another. Yet this is important to the development of theories of field-level change. Do fields develop incrementally over relatively long periods of time or in revolutionary ways over short periods of time? This, of course, begs the question of what, in the context of field-level studies, constitutes long or short periods. Many studies of change are over very long periods of time (e.g., Greenwood et al., 2010; Lounsbury, 2007; Tolbert and Zucker, 1983), but such studies do not address the question of timing in change. Much of the organizational change debate about pace has been within the context of planned or policy-led change (Amis et al., 2004). Are fields more naturally evolving and thus have a tendency to be slower paced in change? And, bringing scope and pace together, are there some elements that change faster than others, for example, as a result of the work of institutional entrepreneurs?

Next in understanding the periodicity of field change is the idea of the linearity of change. Because this is largely ignored, there is an implicit assumption that there is directional consistency in change - all elements move in the same direction, possibly at the same pace. But Bourdieu's work $(1975 ; 1985)$ emphasizes that there is contestation, competition and struggle in fields, and this has become even more apparent with ideas of multiple logics and institutional complexity (Greenwood et al., 2012). As field change occurs, field elements are tugged and pulled between the interests of competing actors and are likely to be characterized by disjunctions, oscillations, reversals of directions and other processes like these.

Understanding the periodicity of field change also means that it is necessary to be clear 
about where a field starts from in that process and where it arrives or ends up. Because most authors do not attend to these issues, we could not make definitive judgments about periodicity in the literature. We encourage researchers to take these aspects into account in the future, particularly when doing comparative work with organizational fields. In general, our categorization of field types requires that we think in more detail about these issues, i.e., what is subject to change, what is the scope of change, the pace of change and the timing of changes, all at the field level. In social movement populations, for example, the key element is ideology; for professional populations, the key element is practice norms; and for industry populations, a key element is market position or status. A change that maintains power positions but changes practices may be convergent for industry exchange fields, but not for professional exchange fields. Conversely, a change that maintains ideology but changes status hierarchies may be convergent for social movement exchange fields but not for industry exchange fields. In order to have a deeper understanding of field-level change, it is necessary to have a more systematic, defined, historical and longitudinal view of change (Pettigrew \& Whipp, 1993). From our review, we move beyond ‘change as disruption' and identify more nuanced patterns of change. We have classified field studies in terms of locus of change (according to field types) and pathways of change (moves between conditions). Indeed, we believe that there is an important research agenda here to clarify, systematize and further the study of institutional change at the field level.

Field types and change. We have described exchange fields organized around populations of industries, professions and social movements, and issue fields including competitive, interstitial and bridging issue fields. In this section, we consider the characteristics of each field type, and review examples from the literature to identify insights about the scope, 
pace and linearity of change in each of the field types, as shown in Table 3.

\section{Insert Table 3 about here}

Exchange fields. In industry exchange fields, industry population members seek optimal distinctiveness (Deephouse, 1999), attempting to be similar enough to be legitimate yet different enough to compete. Efforts to compete and struggles for market share and legitimacy in industry exchange fields lead to significant experimentation and introduction of new/superior practices, structures and technologies, either through the efforts of large incumbents (e.g., Ansari \& Phillips, 2011; Gawer \& Phillips, 2013) or through the innovation of new entrants or peripheral actors (Anand \& Peterson, 2000; Hargadon and Douglas, 2001; Leblebici et al., 1991). While many of these changes are convergent changes that leave status hierarchies largely unchanged (Ansari \& Phillips, 2011), some are more radical and may disrupt status hierarchies considerably (Hargadon \& Douglas, 2001; Leblebici et al., 1991), though their sponsors may attempt to disguise their radicalness in the hopes of maintaining legitimacy (Hargadon \& Douglas, 2001). Because boundaries of industry exchange fields are relatively open, and significant experimentation occurs in the pursuit of optimal distinctiveness, the pace of change has been shown to be fast (Hensmans, 2003; Leblibici et al., 1991). Diffusion may have a more moderate pace, however, and be spotty, as industry members may have commitments to other technologies and practices, or they may wait to see if an innovation will pay off. The differentiation among subfield niches also means that innovations are likely to diffuse to some subfields but not to others. However, change is likely to be rather linear as industry members will pay more attention to their own organizations rather than those of their competitors. The exception is when it comes to industry standards, since defining standards has significant implications for power. As Garud et al., (2002) found with the introduction of a Java standard, change was nonlinear and contested. 
Interaction partners in exchange fields often provide the impetus for diffusion of an innovation as consultants spread practices (Zbaracki, 1998), and industry associations (Buchanan, 2016; van Wijk et al., 2013), insurance companies (Hoffman, 1999), government agencies (Raaijmakers, Vermeulen, Meeus, \& Zietsma, 2015) and others encourage or demand the use of new practices. Social movement exchange fields share many of these characteristics, as they also typically have permeable boundaries, and interaction partners (especially funders) who demand certain practices. Furthermore, because relations are relatively egalitarian with isomorphic pressures for adherence to ideology but not so much to practices, significant experimentation occurs and many innovations are launched. For example, the Slow Food movement described by van Bommel and Spicer (2013) features a wide variety of organizations that have attached themselves to the ideology of slow food, but their practices and foci are wildly divergent. We expect the pace of the introduction of change thus to be fast in social movement exchange fields, with the same moderate and spotty diffusion of changes as we saw with industry exchange fields, as many social movement organizations play divergent roles with different sets of practices (Bertels et al., 2014). The evolution of social movements has been perceived as a process of mobilization and emergence (Morrill, Zald, \& Rao, 2003), suggesting a linear process from mobilization to success or failure. However, studies of social movement dynamics have noted significant nonlinear dynamics. Taylor (1989) studied the women's movement and found it went into a state of abeyance, maintaining a holding pattern during periods of hostile conditions, but resurfaced when opportunity structures improved, however with fragmentation of the core as a parallel process (Sawyers \& Meyer, 1999). Holland and Cable (2002) similarly showed that a local activist core went through two cycles of abeyance and resurgence.

In contrast, in professional exchange fields, change is likely to be primarily convergent, 
and be slow to be adopted, since professional associations are focused on control of practices and experimentation is limited. For example, the approval of the multidisciplinary form in the accounting professional field took a number of years and followed a nonlinear path, as different groups at different times reflected on the change and whether or not it should be adopted (Greenwood et al., 2002). Once a change is adopted by the professional association, however, or mandated by a regulator, the diffusion of the change is likely to be swift. For example, the entry from accounting into legal practice was contested and took some time to be accepted (Greenwood \& Suddaby, 2006). The regulator quickly reversed the change, however, when the Arthur Anderson scandal brought potential problems with the form to the surface, and adherence to the regulator's directive was swift.

Issue fields. In competitive issue fields, relations among populations within the issue field are frequently conflictual during field change processes, often with dense interactions among subgroups and sparse connections between them. Settlements, if reached, are likely to take considerable time, feature nonlinear reversals due to conflict, and they have the potential to be radical because they typically incorporate the interests of multiple actors. Competitive issue fields not only concern industries and social movements (Hoffman, 1999; Zietsma \& Lawrence, 2010), but also concern boundary disputes among professions, such as reallocation of responsibilities in medical fields (Bucher et al., forthcoming; Dunn \& Jones, 2010; Reay \& Hinings, 2005; 2009); between entrepreneurs and incumbents seeking to affect a regulated market (Gurses \& Ozcan, 2015); and between industry and professions, such as between scientists and pharmaceutical companies (Murray, 2010).

Interstitial issue fields will feature much faster, and likely more radical, change because these fields are typically underorganized to begin with. Because they draw infrastructure 
elements from several other fields, change is likely to follow nonlinear processes and its diffusion throughout the field is likely to be spotty. Granqvist and Laurila (2011) describe the emergence of the nanotechnology field comprised of scientists, government officials, entrepreneurs and activists. The field featured many changes as infrastructure was added, and over time the activists were shut out. Similarly, Maguire et al., (2004) describe the emergence of the HIV/AIDS field, which included pharmaceutical firms, patient care advocates, physicians, members of the gay population and others. As the field organized, many new practices, protocols, meanings and structures to manage HIV/AIDS treatment emerged.

Bridging issue fields are likely to primarily produce convergent change, though such changes are likely to add up to significant transformations over time. Each change must be defined in nonlinear negotiation processes that seek to integrate the interests of members of the other fields the issue field is bridging. Though the pace of change is likely to be slow, the negotiated process of change suggests that once members agree on a new practice or meaning, it will diffuse rapidly to all members of the field. For example, O'Mahony and Bechky (2008) describe the coordination of work between firms and members of the open source community involving nonlinear processes of negotiations, surfacing convergent and divergent interests, to define rules. Conflict meant some reversals, but coordination processes established the basis for ongoing collaboration, and a boundary organization managed the field bridging over time, providing pluralistic control, brokering agreements and otherwise managing coordination.

While we have argued the scope, pace and linearity of change will depend on the type of field, change processes will also vary depending on field conditions, as described next.

Field conditions and pathways of change. In considering the relationship between field conditions (established, aligning, fragmented and contested — see Table 2) and change, we look 
to the triggers for change that move fields between these conditional states. We focus on changes in field conditions because our review suggested that any institutional change involved a change in state in fields, even if it was only moving from an established field to aligning around a new practice, rule or organizational form before returning to an established state.

In the past decade, and with the focus on institutional logics within fields, institutional entrepreneurship (and the debates of embedded agency) and institutional work, this shift in theorizing has seen a consequent focus on triggers of endogenous change in fields (Ansari, Wijen, \& Gray, 2013; Battilana, 2011; Battilana \& D’Aunno, 2009; Battilana et al., 2009; DiMaggio, 1991; Lawrence \& Suddaby, 2006; Sherer \& Lee, 2002), as opposed to the rarer exogenous shocks of earlier models (Greenwood \& Hinings, 1996). Such earlier understandings were captured by Greenwood and Hinings (1996) in a model of radical change examining how exogenous shocks enter and infiltrate a field and are translated by its member organizations. Such change was episodic and radical, and not as common in studies of fields as one might expect (for an exception see Lægreid \& Serigstad, 2006; Child et al., 2007). By contrast, institutional drift (Oliver, 1992) focuses more on the gradual changes in institutions that occur as performance slips and meanings shift over time (see for example, Zilber, 2002). Institutional entrepreneurship (Battilana et al., 2009), diffusion (Kennedy \& Fiss, 2009; Lounsbury, 2001; Purdy \& Gray, 2009), and the influence of field-configuring events (Garud, 2008; Lampel \& Meyer, 2008), which provide a context for interaction between hitherto unconnected parties (Glynn, 2008), have all been implicated in endogenous change processes. Indeed, by emphasizing issue fields, what might otherwise be seen as exogenous (e.g., activist pressure) becomes endogenous, as new actors enter issue fields when they engage with exchange field members to pressure for change on a particular issue. 
Triggers for change. A number of studies of institutional change that we reviewed focused on changes within industry populations, predominately triggered through internal competition. When industry populations are experiencing stagnating or declining revenues, or when new technology, business models or organizational structures are introduced, competition triggers changes in relations and practices (Furnari, 2014; Garud, 2008; Munir \& Phillips, 2005). These innovations may be introduced by incumbents, such as was the case for mobile telephony (Ansari \& Phillips, 2011), and multidisciplinary practice organizational forms (Greenwood et al., 2002), often preserving power and status hierarchies. Alternatively, when peripheral actors introduce innovations, status hierarchies may be remade. For example, when Edison introduced electric lighting, the market transition away from gas lighting disrupted the previous market leaders (Hargadon \& Douglas, 2001). Similarly, Kodak, long dominant in the photographic industry, suffered significant losses when digital photography moved from the margins to mainstream, overtaking film-based photography (Munir \& Phillips, 2005). Some studies show how incumbents seek to preserve their power and status by purchasing innovations. For example, Billboard, the dominant provider of hit charts in the music business, purchased its disruptor, the new entrant Soundscan, in order to maintain its role as market information provider (Anand \& Peterson, 2000). The more reliable and valid data produced by Soundscan's technology did maintain Billboard's dominance, but it changed the hierarchy of genres in the music business. Similarly, when peer-sharing upstart Napster disrupted the recording industry association (Hensmans, 2003), Bertelsmann eventually bought the company, though the recording industry has never been the same.

Our classification of the field conditions of empirical studies across the literature suggests that there are discernable patterns of field change in competition within exchange fields. The 
studies we saw where change was stimulated by internal elite actors showed fields progressing from established conditions into aligning (or realigning) states, as new technologies, forms or other innovations were adopted (Mazza and Pedersen, 2004). The change happened in a more evolutionary and convergent way, leaving power and status hierarchies largely as they were. Exceptions occurred when exchange fields contained both professions and industry populations, each embedded in their own separate, though linked, population-level institutional structures (see also Abbott, 2005). While industry populations introduced changes, professional associations were often resistant, making change take longer and creating more conflict (Greenwood \& Suddaby, 2006; Smets et al., 2012). On the other hand, when change was initiated by peripheral actors, exchange fields became contested, with elite incumbents attempting to protect their positions either by resisting change or co-opting its source (Anand \& Peterson, 2000; Hensmans, 2003; van Wijk et al., 2013).

We also observed in industry populations that triggers for endogenous change may arise through field-configuring events (Anand \& Jones, 2008; Anand \& Watson, 2004), and the creation of new subfields (Anand \& Watson, 2004; Lepoutre \& Valente, 2012) by existing members around a particular issue. For example, Lepoutre and Valente (2012) found that members of Belgian horticulture created a subfield around the issue of being an organic producer. Similarly, Anand and Watson (2004) showed how field members created a new category within the field of publishing and established it through the Booker Prize, as a fieldconfiguring ritual. Subfields may be created from members gathering on an issue, resource, category or new technology — they essentially form a strategic actor group (Fligstein \& McAdam, 2012) within a larger field and become a source of change, and in doing so, gain some immunity from isomorphic pressures from the mainstream field (Lepoutre \& Valente, 2012). 
Exchange fields may also have change triggered through the introduction and translation of new infrastructure such as categories, rankings and organizational forms. These may come from incumbents (Greenwood \& Suddaby, 2006), in which case power structures are often reinforced, or from new actors, such as U.S. News' entry into ranking of legal education (Sauder, 2008). If such a change is introduced by a new or peripheral actor, this new infrastructure, especially ratings, rankings and awards, reconfigures relations within a field, and is often used to disrupt established power bases (Sauder, 2008) by changing the social evaluations of reputations and status of actors conducted within the field (George, Dahlander, Graffin, \& Sim, 2016). Such innovations are often legitimated by the pressures and logics drawn from broader society or nearby fields (Greenwood \& Suddaby, 2006; Guillen, 1997; Kim, Shin, Oh, \& Jeong, 2007; Sauder, 2008).

In our review, we found that many exchange field members are drawn into issue fields when the State imposes a change or a social movement pressures for one. Within fields, governments may create and formally legitimize new actors (Borum, 2004; Child et al., 2007), and introduce new laws that change relational channels or required field practices (Castel \& Friedberg, 2010; Currie, Lockett, Finn, Martin, \& Waring, 2012; Nigam \& Occasio, 2010; Oakes et al., 1998; Orsato et al., 2002; Raajmakers et al., 2015; Reay \& Hinings, 2005). Regulatory changes or policy interventions might be directly imposed from above (Windeler \& Sydow, 2001) or by formulating policy priorities and changing resource patterns (Swan, Bresnen, Robertson, Newell, \& Dopson, 2010; Sydow et al., 2012). A common feature is seeking balance between various sub-populations in the newly defined field, as has been repeatedly shown for health exchange fields (Arndt and Bigelow, 2000; Blomgren, 2007; Kitchener, 2002). When the State does take such action, the resulting change is varied, depending on actor position and 
ability to resist or delay implementation (Barley, 2010; Orsato et al., 2002), and the existence of societal support and broader public pressure (Borum, 2004; Kim et al., 2007).

We note here that societal pressure also manifests in issue fields through social movements concerned with certain aspects of field activity and practices, such as environmental practices (Hoffman, 1999; Maguire \& Hardy, 2009), or through minority or previously silenced actors, such as those fighting protection payments to the Mafia (Vacarro \& Palazzo, 2015). Because issue fields often feature dialectical processes among diverse actors, the settlement of contentious issues may be only temporary (van Gestel \& Hillebrand, 2011).

Additionally, studies of newly emerging fields with sparse infrastructure begin either in fragmented states (where the prioritization of logics has yet to be determined) or aligned states (where there is broad agreement on the prioritization of logics). In reviewing these studies, we found that fields often form and change around opportunities, such as the pursuit of a promising new technology (cochlear implants in Garud, 2008; photography in Munir \& Phillips, 2005; and nanotechnology in Meyer, Gaba \& Colwell, 2005), a new market or area of practice (e.g., consulting in Kipping \& Kirkpatrick, 2013; information schools in Patvardhan et al., 2015), or to take advantage of a regulatory shift (Purdy \& Gray, 2009). A less elaborated institutional infrastructure, or one that is fragmented, provides space for innovation and also weaker points in field boundaries, enabling entry of new actors. For example, Kipping and Kirkpatrick (2013) describe how new actors enter a weakly professionalized field from the margins. Fields also emerge through opportunities provided by changes in government regulation (Purdy \& Gray, 2009) and through events that draw in actors from previously disparate fields (Meyer, Gaba \& Colwell, 2005; Oliver \& Montgomery, 2008). These interstitial spaces are generative for new collaborations and provide space for new systems of meaning and relations to be worked out 
(Furnari, 2014; Medvetz, 2012). Studies of emerging fields suggest that even in aligned fields, there is a tendency to return to fragmentation, especially with the entry of new actors with different perspectives (e.g., Kipping \& Kirkpatrick, 2013; Patvardhan et al., 2015).

Pathways of change. In reviewing field-level studies of change, we identify six pathways of change based on triggers that move a field from one condition (see Table 4) to another. We present sample studies that illustrate these pathways in Table 5. We recognize that there is a success bias in the studies of institutional change that are selected for publication, and that as a result, there are more possible pathways and triggers. Furthermore, we are largely unable to draw firm conclusions about what matters in institutional change because we have few examples of pathways that lead to failure rather than success, and we strongly encourage such research on failure. However, the pathways we identify in the literature represent relatively consistent patterns and identify some possibilities that should be evaluated further in future research.

Insert Table 4 and 5 about here

The pathways we identify represent conditional moves in fields, distinct from previous understandings of field change based on the passing of time (e.g., mature or emergent). A field may move from an established condition where, as we previously described, there is highly elaborated institutional infrastructure with distinct dominance orders and actor positions, to a condition of (re)aligning or contestation. From a field condition of established to one of (re)aligning, change is usually observed through incremental changes, with incumbents, elites or central actors often managing the change. This incremental change sees the field realigning around new practices or relational channels, and adjusting institutional infrastructure. Triggers for this move may be the introduction of a new technology, law or arbiter of taste, perhaps involving competitive moves within the field. For example, Anand and Watson (2004) show how 
the introduction of Grammy Awards in the commercial music industry shifted field attention by generating prestige, impacting actor positions and status over time. The Grammy ritual reordered relations by creating new and stronger linkages between retailers, artists and producers. While both exchange and issue fields can make this move from an established state to a realigning one, we are much more likely to see it among exchange fields (Ansari \& Phillips, 2011; Oakes et al., 1998), since issue fields are less likely to be established to begin with. Issue fields that are established are likely to have achieved settlements with difficulty, through negotiations, because of the different logics that exist in such fields. Any change might require extensive and iterative renegotiations to achieve. The exception might be seen with bridging issue fields if changes are relatively minor and convergent with established status orderings. These ideas remain largely speculative, however, as there have been few studies of issue fields that are established.

Another common pathway is the movement from an established to a contested field condition. Moving to a contested state often occurs through more disruptive change, either an exogenous shock or through the challenging of status quo by a new or peripheral actor (Hensmans, 2003), a coercive change via new regulation, or perhaps the tipping point is a social movement or arbiter of taste where existing rules of the game are publicly called into question (Sauder, 2008). Reay and Hinings (2005) show how the established field of healthcare in Alberta became contested when a new government-led healthcare reform strategy was implemented and legislated. This coercive change abruptly introduced a new logic into the healthcare system, previously grounded in a logic of medical professionalism, to a new logic of business-like healthcare. In order to accomplish this change, the government first implemented structural changes that were radical and occurred at a revolutionary pace (Greenwood \& Hinings, 1996), such as funding models, governance systems, roles and responsibilities. Alternatively, 
contestation may arise not from peripheral actors or central actors, but from a breach in the rules of the game by a central actor (or the revelation of such breaches). For example, WikiLeaks and the News of the World both used the same practices to make the public private, and in doing so disrupted traditional circuits of power and established fields of journalism and news reporting, contributing to significant contestation (Logue \& Clegg, 2015). In many cases, this move from established to contested corresponds to a move from an exchange field to an issue field, as new actors with different logics enter the field and challenge practices (Hoffman, 1999; Zietsma \& Lawrence, 2010).

Other pathways of field change include a move from a fragmented condition to one that is aligned (or aligning) or contested. In moving from fragmented to aligning, we observe how underorganized domains with little coordination of action or relations and limited institutional infrastructure begin to converge around certain ideas, rules, positions and actors. Many studies have demonstrated this pathway of field change through the analysis of field-configuring events, where previously disparate actors come together and through collective sense-making develop shared systems of meaning (Garud, 2008; Zilber, 2007). Oliver and Montgomery (2008) show how such a shift can occur through the intensity of a single meeting, in their analysis of a professional conference at a pivotal moment in the emergence of the Jewish lawyers group in pre-state Israel in 1944. The shared cognitions developed in this fragmented space led to an alignment in the field and the consequent growth in the Jewish legal profession and Jewish judges, use of Hebrew in courts and establishment of an Israeli bar. This move is most commonly seen in interstitial (Granqvist \& Laurila, 2011) and bridging issue fields (Hardy \& Maguire, 2010; Helms et al., 2012), but may also be seen in exchange fields.

A field may also move from a fragmented to a contested condition, where in the process 
of a field emerging, rules, roles and resources are a source of struggle as disparate actors tussle for position. In Washington's (2004) study of the US National Collegiate Athletic Association, the analysis of the central actor shows the evolution of a field moving from fragmented to contested (and eventually aligning) over an almost 100-year time period; contestation in fields may exist for a significant duration. This move is likely in both exchange (Patvardhan et al., 2015) and issue fields (Hardy \& Phillips, 1999).

Other pathways of change include a field moving from a condition of contestation to one of alignment or establishment (noting that such a pathway is often observed as a second-order move in a field study given it assumes prior field existence). Many studies situate their field analysis in this conditional context - a setting of field contestation - then examine how the contestation played out and the processes by which a field eventually (re)settles or coheres (avoiding assumptions of linear change here). In such settings, as disputes and rules get worked out, an issue field may revert to or become an exchange field, and actors may (re)align around new logics or through new relational channels. Zietsma and Lawrence (2010) show the expansive scope of changes that led to the significant realignment of the forestry industry in British Columbia after a period of contestation, including through new actors, social movements and regulatory changes, to get to an eventual settlement on legitimate practices of forestry. Similarly, Meyer and Höllerer (2010), present a historical case of the dissemination of the Anglo-American idea of "shareholder value" of corporate governance, and its contestation in Austria given its challenge to the local consensus on the role and purpose of corporations. This struggle over meaning plays out over time, permeating the public discourse with Austrian corporations gradually displaying commitment to this orientation, realigning the field around a changed meaning system. 
When a field moves from being contested to established, this pathway of change often sees fields being settled abruptly (as they skip a condition of aligning). This may be triggered by the introduction of a new law or actor that settles disputes or elite-driven convergent change. Examples of this abound in Gurses and Ozcan's (2015) historical analysis of the introduction of cable television into the U.S. and the role of market regulation and courts in settling field disputes - in this case often in favour of the market incumbents due to their close relations with regulators. Holm (1995) showed a similar pattern in the Norwegian fishing industry. This path is likely in both issue and exchange fields.

While we identified six common pathways of field change (from one condition to another), fields feature multiple pathways over time. The pathways we identify represent conditional moves in fields. Fields may feature multiple pathways (or moves from one field condition to another) over time. For example, Hargadon and Douglas (2001) showed how the established gas light industry field was contested by the innovation of the electric light, causing the need for incumbents to realign to this challenge from a peripheral actor and new technology, eventually settling and reestablishing. The less common moves observed in our review included from an established condition to a fragmented condition (arguably rare occasions where an existing field suffers an exogenous shock that decimates the field) and from a fragmented to an established condition (arguably rare occasions where the working out and struggling over rules, positions and meaning are skipped and instead settled immediately by a top-down force or regulatory decision). We also suggest the moves from aligning to contested, or aligning to fragmented, are more temporary states, as fields begin to get some coherency in their evolution or emergence, and struggles and disputes flare up again causing contestation or fragmentation. A pathway from a contested field condition to a fragmented condition suggests field disputes that 
cannot be resolved and the field fails to emerge or cohere. A pathway from an aligning field condition to an established condition usually involves a process of convergence and is commonly observed as a second-order move in the studies reviewed. This pathway is quite common in the institutionalization of a field (Munir \& Phillips, 2005).

While our analysis here focuses on merely one move in field conditions, it is likely there are stable and consistent patterns that combine multiple moves. These patterns are likely to vary by trigger for change, position power of agents involved, type of field and condition of field at outset. Initial examination of Table 5 and Appendix 1, which classify institutional change studies on these elements, suggests patterns such as elite-driven convergent change, interstitial issuefield emergence and settlement, new entrant-driven radical change, endogenous subfield development, contested issue-field war and settlement, etc. These change patterns are likely to have systematic influences on the pace, linearity and scope of change. Because each study in the literature had a particular area of focus and necessarily excluded some elements, comprehensive assessment based on prior research would be incomplete and tentative only. Future research using qualitative comparative analysis might be one means to discern and evaluate such patterns, and we encourage such field-comparative approaches.

\section{Conclusions and Research Agenda}

As Powell, Oberg, Korff, Oelberger and Kloos (forthcoming) note, “organizational fields have changed over the past four decades - they are more dynamic, boundaries are more porous, different organizations have come to populate them, and the power differentials among members have been altered, in part as a result of the advent of the World Wide Web. As a consequence, different relational possibilities are altering the configurations of fields." We believe theory has not caught up to changes in society. Our starting point in all of this is to emphasize difference- 
something that has been lost in institutional theory (Greenwood, Hinings, \& Whetten, 2014). Our review shows that there has been little concern with systematically analyzing field differences, as a result of which it is not possible to know whether the basis of comparison between field-level processes such as diffusion, isomorphism and institutional complexity is reliable. It is only by knowing what kind of field those processes are located in that real comparison can be made. This is very much in line with a concern in organization theory generally with classification (Fiss, 2007; Meyer, Tsui \& Hinings, 1993). Thus, to help organize and summarize the literature reviewed, we first elaborated field types and examined field conditions, from which we can better understand the nature of any field that we study, and then we theorized how those differences interact with agency and change.

Our review of the different, overlapping definitions of fields led us to note two types of fields: exchange fields and issue fields, based on the purposes that fields serve, with three subtypes each. Within fields we suggested that there are three types of populations-industry, professional and social movement — although we acknowledge that these may be further segmented into subfields like strategic groups for industry fields, or specialists within professional fields, and that other types of subfields may exist.

While we could categorize our fields according to relatively simple criteria, the various fields are not evenly covered by empirical studies - clearly more comprehensive studies have been conducted on industry fields, with social movement fields being a recent addition. Much of what we reviewed has been described by researchers publishing on these fields in the same terms. For issue fields we suggest that there are three configurations that arise from previous studies, interstitial, competing and bridging issue fields. This reflects a much more recent wave of studies on issue fields as the core subject of research, leading to a new categorization labeled 
on the basis of the findings of relevant studies, though the authors of these papers may not recognize these labels. In ordering the findings in these three categories, we seek to clarify research on issue fields.

Moreover we concluded that there is an important relationship between exchange fields and issue fields. When issue focused actors engage with exchange fields, exchange fields convert to issue fields, often fostering changes in logics or other field elements. For example, Galvin (2002) documented how the medical field, dominated by the medical profession, became fragmented and complex as consumers and interest groups brought new issues into healthcare. Similarly issue fields may revert to exchange fields, as the issues that prompted competitive issue fields become encompassed in exchange fields' institutional infrastructure. In Galvin's longitudinal study, new professional groups and field actors arose to manage the issues that consumers and interest groups brought to healthcare, in what we interpret as embedding these issues into a realigned exchange field. Other logical transformations that have been suggested are the development of new industries from an interstitial issue field such as recycling (Lounsbury, 2001). This opens the possibility of an evolutionary model of fields, as yet not explored in research, and studies are needed to examine the conditions by which one type of field can evolve into another.

In our review we identified fields in which professional and industry populations cohabit a domain and mutually support one another. The prime example might be the healthcare industry and the medical profession. While extensive studies have been done on this partnership, and on others such as the accounting and legal professions and the accounting and law industries (Greenwood et al., 2002; Greenwood \& Suddaby, 2005; Smets et al., 2012), it is also the case that virtually every industry exchange field interacts with professions to a greater or lesser 
extent, and while prior work has argued that professions serve as a stabilizing influence within fields, it is also likely that they serve as a conduit for innovations across industry exchange fields.

In terms of a research agenda, our field types point to a number of issues. First, there is the need to further test the distinction between exchange and issue fields; for us this is a starting point, one that we believe is robust in that it has been derived from extant definitions of fields and from comparisons of studies in the literature. We have not focused on other types of fields, such as state fields, or interlinked policy fields that overlap with (Evans \& Kay, 2008), but may sit at a hierarchically higher level than the issue and exchange fields that we describe (Holm, 1995). Such fields require further exploration, as do transnational governance fields and influences (Djelic \& Sahlin-Andersson, 2006). Second, the dynamics of the subfield populations that we outline need empirical investigation, together with a search for other subfield populations. All of this is part of the important element of systematically elaborating different actors within a field, their common meaning systems and their homogeneity and heterogeneity. Third, we believe the relationship between issue fields and exchange fields is a particularly fruitful area of research. When and how do issue fields revert to exchange fields if settlements are negotiated on issues? Do exchange fields then include the new actors that were involved in the issue field, or do their issues become codified in exchange field infrastructure, enabling them to disengage with the field itself? Studies in this area might profit from a mapping of field evolution over longer periods of time than the usual episode-driven field studies we encountered as the dominant form. The more limited focus of such studies is a by-product of journal page limitations and we need to caution the reader that this gap is partly artificial. Studies that show a broader and more encompassing picture are typically published in book form (see e.g., Scott, et 
al., 2000).

Our analysis of field conditions is also predicated on differences in logics and institutional infrastructure (Greenwood et al., 2011; Hinings et al., forthcoming; Raynard, forthcoming). We categorize fields in terms of whether there are settled or unsettled logic prioritizations and limited or elaborated institutional infrastructure. This produces a four-fold classification of field conditions, namely, aligned/aligning, fragmented, established and contested. Such a classification captures most of the elements that have been important in research on fields.

There is an important research issue from this elaboration of field conditions in its own right: to relate such conditions to the field types. What is the existence of, for example, a fragmented exchange field or a contested issue field? Do all field conditions exist in both types of field? In any classification scheme it is important to know the actual distribution of the different types. Of course, a further important research topic is to utilize the field types and conditions to understand agency and change, which we turn to next.

Indeed, our review demonstrates that these field types and field conditions have significant impact on both the agency of actors within a field and on processes and pathways of change. Our examination of agency stresses the heterogeneity of actors, once again asserting that institutional theory has not taken the variety of actors seriously. Indeed, field studies tend to concentrate on a very limited set of actors. We suggest that actors can be characterized by their position in the field: central/elite actors, peripheral or marginalized actors, middle status actors and interstitial positions. They can also be characterized by their roles or functions, such as fieldstructuring or governing organizations, formal governance units, field coordinators or arbiters of taste. The point is that there are usually many and varied actors in a field. Their agency is 
structured by the kind of field and subfield they are part of and the heterogeneity/homogeneity of actors involved. Thus, institutional fields are significantly more heterogeneous than many institutional theorists have suggested (Scott, 2014).

In terms of future research, an important question is, given such heterogeneity, what are the sources and powers of isomorphism? Who is embedded in what? We believe that our approach and analysis suggest new conceptualizations and direction for the examination of embedded agency.

Finally, and in many ways the centerpiece of our argument, is the relationship between types of fields, field conditions and field-level change. While we believe strongly in classification, any typology or taxonomy is useful only in terms of what it helps us to explain. As more and more fields studies have become concerned with multiple logics (institutional complexity) and field-level change (Greenwood et al., 2011; Thornton et al., 2012), examining different kinds of field change is critical for understanding both similarity and difference in change processes. Indeed, we identified different patterns of change and we suggested as a starting point six common pathways distilled from the empirical literature.

Essentially, what we have outlined in Table 4 represents a set of hypotheses for future research, elaborating the relationships between field types, field conditions, agency and change. It represents the crux of our arguments that emphasize taking difference seriously. As institutional theory has moved from a concern with diffusion and isomorphism to a concern with embedded agency, field change and institutional complexity, so there is an increasing concern with differences between and within fields. Through the concept of pathways of change we hypothesize how change occurs in these different sets of field circumstances. This represents a major research agenda as we go forward, attempting to empirically validate these pathways, 
identifying others, and through that work, tightening up the scaffolding of theorizing on institutional fields. There is much to be done.

Our thrust is to produce a comprehensive conceptual framework, allied to important theoretical issues as a way of moving the study of fields forward. We have shown that there is an absence of systematic analysis in examining fields as a result of which it is difficult to produce comparative, cumulative research. In putting forward a research agenda, we are arguing that the most important basis for comparative, cumulative research is the use of the same or very similar conceptual frameworks. In this sense, this paper seeks to do for fields what Thornton et al. (2012) set out to do for institutional logics, to "lay the groundwork for the continued development of this progressive research program" (Thornton et al., 2012: 170). Such an approach puts conceptual development ahead of empirical evaluation. Indeed, strong conceptual frameworks and elaborated theoretical schema allow better evaluation of the empirical basis of different studies because such an evaluation is initially driven by relevance for, and contribution to, theoretical development.

Our approach allows us to be agnostic about research design, methods and data analysis. The studies that we have reviewed use a range of methods. While we recognize that all studies in all methods focus on particular features of institutional fields and ignore others, and thus we cannot treat the studies we reviewed as complete depictions of organizational fields, our aim has been to utilize those studies to build initial concepts and theoretical propositions, which can be examined in future work. Design, methods and analysis are relevant to the particular concepts and propositions being examined. We urge more comparative analysis, but such analysis can be in-depth comparisons between two fields, or less deep, more outline comparisons between many fields. Indeed, institutional theory has shown (to us) a welcome embrace of multiple designs, 
methods and analysis. Again, we agree with Thornton et al.'s (2012: 184) reflection on studies of logics, "the strength of the foundational studies of the institutional logics perspective has been on the triangulation of types of data and methods of analysis — being reliant on both qualitative and quantitative methods." We recognize the same strengths in studies of fields and would expect that diversity to continue. What we are pleading for is embracing an articulated set of concepts about fields, field processes and field change.

\section{Additional Research Directions}

While we feel a rich research agenda is associated with our categorization of fields in this paper, there are also a number of outstanding issues that we could not give full attention to in this review, but which represent promising new directions for future research. We describe three: interstitial issue fields, field to field interactions and societal problems and fields.

Interstitial issue fields. An interesting direction for future research would be to examine how organizations in interstitial positions manage connections to multiple fields. Further, are there different dynamics associated with permanent versus temporary interstitial organizing? Are there specific advantages or disadvantages of interstitial emergence with the borrowing and blending of adjacent field infrastructure and logics that this implies, or do all fields begin as issue fields in interstitial spaces? Future work is needed. Such work is likely to provide insights for research on cross-sector partnerships and hybrid organization. While these organizations have typically been considered rather independently of field locations, addressing them as interstitial organizing may suggest different means of identifying and addressing barriers to collaboration, contestation about meanings and practices, and means of organizing that could better manage the field to field connections and institutional integration that is required in interstitial organizing.

Field to field interactions. With the elaboration of different types of fields, the location of 
these ordered social spaces in the overall structure of society requires more attention. One direction would be to use our distinctions to more systematically study the effects of field to field interactions, an area that remains both under-theorized and under-explored empirically.

We note several promising beginnings. Evans and Kay (2008) studied the negotiation of the North American Free Trade Agreement and the relative success of the labor and environmental social movement fields in influencing what they term a hostile trade policy field. They claimed that the structure of field overlaps enabled mechanisms of influence including alliance brokerage, rule-making, resource brokerage and frame adaptation. Van Wijk et al. (2013) examined the intersection of the emerging sustainable tourism movement field with the established Dutch outbound tourism industry field, finding that the relative permeability of the movement field induced the industry field to attempt to co-opt the movement with collaboration. Instead, the co-optation was mutual as the movement field and industry field co-structured the issue field together.

Thinking about these influences as field intersections rather than as field outsiders attempting to influence a field or conflict within issue fields (Hoffman, 1999), suggests different ways to understand the source and persistence of multiplicity in organizational operations. While a significant number of studies have appeared on the interactions of different populations in the healthcare industry, most of these studies focus on localized interactions between relevant groups like doctors and state administrators (Reay \& Hinings, 2005), and medical and public health educators (Dunn \& Jones, 2010). Field members also interact with members of other fields, either in regular exchange relationships or in issue-focused debates that arise due to exogenous changes (Hoffman, 1999). Moreover, field members interact in a more diffuse manner with other fields bringing in practices and resources from other fields (Greenwood et al., 2002; Smets et al., 
2012). These are promising beginnings in theorizing interfield relationships, but we feel that much more work is warranted in this area.

Institutional theory could benefit by drawing on concepts from related literatures. Some work has been focusing on field to field interactions using an ecological perspective (Abbott, 2005; Freeman \& Audia, 2006), acknowledging that fields function in wider environments, with linkages to other fields. However studies of fields and field dynamics have paid little attention to these ideas. Attention to the external connections of a field and considering through which mechanisms legitimacy, resources and political support are transferred to its constituents might provide a fruitful research area.

First, using the concept of audiences, derived from the turn towards contextualization and attention to community embeddedness in organization ecology (Freeman \& Audia, 2006), might help to identify the way in which a field and its purpose are perceived and supported by external actors. Second, further exploring field to field interactions might enable us to better understand how these interactions shape internal field processes. Abbott (2005) emphasized that audiences are in their own ecologies, but that ecologies are often linked. For example, academic disciplines are differentiated but remain linked in areas of methodology, research practices, conferences, etc. Furthermore, they are also linked to universities, students and businesses through technology transfer offices. There are settlements that connect each linked ecology, and these settlements are both cross-cutting and overlapping.

Abbott suggested two mechanisms that could connect fields: hinges and avatars. Hinges are mechanisms or settlements that provide rewards for parties in different fields. For example, proponents of recycling in universities and actors in the recycling industry (Lounsbury, 2001) might work together to influence a specific type of government regulation since both fields 
benefit. Avatars are a mechanism by which one ecology creates a version of itself to be embedded in another ecology. Further developing this line of reasoning could, for instance, clarify the manner in which issues either form a transformative force from the outside criticizing the practices in industry fields or work from the inside, with the risk of losing focus as their host fields transform them over time. These ideas can be connected to work on social movements that compares the effects of insider versus outsider activists on change (Briscoe \& Gupta, 2016).

In yet another conceptualization of potential interactions between fields, Furnari (2016) theorized the relations between fields, building on resource dependence theory. He discussed institutional fields as linked arenas and claimed that interfield resource dependence between fields, specifically mutual dependence and power imbalance, impacts the institutional work done by members of each field and shapes the existence and nature of institutional change that is likely to result. These recent discussions point to the potential benefits of a further exploration of field to field interactions by combining different theoretical traditions, as Liu and Emirbayer (2016) have suggested, noting the complementarity of the field approach with insights from ecological thinking. Similarly, studies might make more substantive use of the progress made in the study of social movement fields (e.g., Diani, 2013; Diani \& Pilati, 2011). We can surmise that combining these recent discussions in one framework with the distinction in three types of exchange fields and issue fields we made, might lead to a fruitful empirical research program. Societal problems and fields. Fields are by nature constellations of organizations that uphold standards together, negotiate or fight over change, or express conflicting interests. Yet their interests are typically rather narrow when compared to the "wicked" problems (Rittel \& Webber, 1973) facing global society, such as climate change (Wijen \& Ansari, 2007; Wright, Nyberg, \& Grant, 2012), the global financial crisis, poverty (Mair, Marti, \& Ventresca, 2012), 
the Zika virus or Ebola outbreak, income inequality (Lawrence, Amis, Munir, Hirsch, \& McGahan, 2014), terrorism and others. These issues, and many more mundane issues such as water governance and air pollution cannot be settled within fields; they demand the ability to analyze issues involving (and across) multiple fields - they demand interfield action. Further work on field to field interactions may help to address this concern. While we have restricted our analysis in this article to a better understanding of individual fields, with suggestions for interfield relationships based on our analysis of issue fields, we believe that the scaffolding we have developed in this review can be helpful for understanding interfield relationships because it helps us to understand where shared meanings and other institutional infrastructure elements exist that may prevent change, or that may be leveraged to enable change. Furthermore, work on issue fields suggests the means by which societal concerns can be encompassed in issue fields of their own, with potential pathways for the formation of new institutional infrastructure to address societal issues. As our review has suggested, in many ways issue fields are the mechanism by which rising societal issues are incorporated into the institutions of exchange fields, enabling adjustment in what otherwise may be somewhat durable arenas for social coordination. There is significant work to be done examining societal problems and collective action, however, and we both encourage this work and are in turn encouraged to see a number of initiatives in the management field focused on addressing these grand challenges of society.

In this article, we aimed to review the state of the art on fields and, based on that review, to build some theoretical scaffolding to enable the further development of studies on institutional fields. We hope that we have at least gone some way to achieving our objective of stimulating additional research, and more focused research, that enables future theoretical development. 


\section{REFERENCES}

Abbott, A. 1988. The system of professions: An essay on the division of expert labor. Chicago: University of Chicago Press.

Abbott, A. 2005. Linked ecologies: States and universities as environments for professions. Sociological Theory, 23(3): 245-274.

Adler, P. S., \& Kwon, S. W. 2013. The mutation of professionalism as a contested diffusion process: Clinical guidelines as carriers of institutional change in medicine. Journal of Management Studies, 50(5): 930-962.

Akemu, O., Whiteman, G., \& Kennedy, S. 2016. Social enterprise emergence from social movement activism: The Fairphone case. Journal of Management Studies, 53(5): 846877.

Amis, J., Slack, T., \& Hinings, C. R. 2004. The pace, sequence, and linearity of radical change. Academy of Management Journal, 47(1): 15-39.

Anand, N., \& Jones, B. C. 2008. Tournament rituals, category dynamics, and field configuration: The case of the Booker Prize. Journal of Management Studies, 45(6): 1036-1060.

Anand, N., \& Peterson, R. A. 2000. When market information constitutes fields: Sensemaking of markets in the commercial music industry. Organization Science, 11(3): 270-284.

Anand, N., \& Watson, M. R. 2004. Tournament rituals in the evolution of fields: The case of the Grammy Awards. Academy of Management Journal, 47(1): 59-80.

Ansari, S., \& Phillips, N. 2011. Text me! New consumer practices and change in organizational fields. Organization Science, 22(6): 1579-1599.

Ansari, S., Wijen, F., \& Gray, B. 2013. Constructing a climate change logic: An institutional perspective on the "tragedy of the commons". Organization Science, 24(4): 1014-1040.

Armstrong, E. A. 2002. Forging of gay identities: Organizing sexuality in San Francisco, 1950-1994. Chicago: University of Chicago Press.

Arndt, M., \& Bigelow, B. 2000. Presenting structural innovation in an institutional environment: Hospitals' use of impression management. Administrative Science Quarterly, 45(3): 494-522.

Barley, S. R. 2010. Building an institutional field to corral a government: A case to set an agenda for organization studies. Organization Studies, 31(6): 777-805.

Battilana, J. 2011. The enabling role of social position in diverging from the institutional status quo: Evidence from the UK National Health Service. Organization Science, 22(4): 817834.

Battilana, J., \& D’Aunno, T. 2009. Institutional work and the paradox of embedded agency. In T. Lawrence, R. Suddaby, \& B. Leca (Eds.), Institutional work: Actors and agency in institutional studies of organizations: 31-58. Cambridge, U.K.: Cambridge University Press. 
Battilana, J., \& Dorado, S. 2010. Building sustainable hybrid organizations: The case of commercial microfinance organizations. Academy of Management Journal, 53(6): 1419-1440.

Battilana, J., Leca, B., \& Boxenbaum, E. 2009. How actors change institutions: Towards a theory of institutional entrepreneurship. Academy of Management Annals, 3(1): 65-107.

Battilana, J., \& Lee, M. 2014. Advancing research on hybrid organizing - Insights from the study of social enterprises. Academy of Management Annals, 8(1): 397-441.

Baumard, P., \& Starbuck, W. H. 2005. Learning from failures: Why it may not happen. Long Range Planning, 38(3): 281-298.

Beckert, J. 1999. Agency, entrepreneurs and institutional change: The role of strategic choice and institutionalized practices in organizations. Organization Studies, 20:777-99.

Beckert, J. 2010. How do fields change? The interrelations of institutions, networks, and cognition in the dynamics of markets. Organization Studies, 31(5): 605-627.

Benford, R. D., \& Snow, D. A. 2000. Framing processes and social movements: An overview and assessment. Annual Review of Sociology, 26: 611-639.

Bertels, S., Hoffman, A. J., \& DeJordy, R. 2014. The varied work of challenger movements: Identifying challenger roles in the US environmental movement. Organization Studies, 35(8): 1171-1210.

Blomgren, M. 2007. The drive for transparency: Organizational field transformations in Swedish healthcare. Public Administration, 85(1): 67-82.

Borum, F. 2004. Means-end frames and the politics and myths of organizational fields. Organization Studies, 25(6): 897-921.

Bourdieu, P. 1975. The specificity of the scientific field and the social conditions of the progress of reason. Sociology of Science, 14(6): 19-47.

Bourdieu, P. 1985. The social space and the genesis of groups. Theory and Society, 14(6): 723744.

Bourdieu, P. 1999. Rethinking the state: Genesis and structure of the bureaucratic field. In G. Steinmetz (Ed.), State/Culture: State-formation after the cultural turn: $53-75$. New York: Cornell University Press.

Bourdieu, P. \& Wacquant, L. 1992. An invitation to reflexive sociology. Chicago: University of Chicago Press.

Brint, S. \& Karabel, J. 1991. Institutional origins and transformations: The case of American community colleges. In W. Powell \& P. DiMaggio (Eds.), The new institutionalism in organizational analysis: 337-360. Chicago: University of Chicago Press.

Briscoe, F. \& Gupta, A. 2016. Social activism in and around organizations. Academy of Management Annals, 10(1): 671-727.

Briscoe, F., \& Murphy, C. 2012. Sleight of hand? Practice opacity, third-party responses, and the interorganizational diffusion of controversial practices. Administrative Science

Quarterly, 57(4): 553-584. 
Briscoe, F., \& Safford, S. 2008. The Nixon-in-China effect: Activism, imitation, and the institutionalization of contentious practices. Administrative Science Quarterly, 53(3): $460-491$.

Buchanan, S. 2016. Trade associations and the strategic framing of change in contested issue organizational fields: The evolution of sustainability in the Canadian mining industry, 1993-2013. Unpublished doctoral dissertation. York University, Toronto.

Bucher, S.V., Chreim, S., Langley, A., \& Reay, T. (in press). Contestation about collaboration: discursive boundary work among professions. Organization Studies.

Cardinal, L. B., Sitkin, S. B., \& Long, C. P. 2004. Balancing and rebalancing in the creation and evolution of organizational control. Organization Science, 15(4): 411-431.

Castel, P., \& Friedberg, E. 2010. Institutional change as an interactive process: The case of the modernization of the French Cancer Centers. Organization Science, 21(2): 311-330.

Child, J., Lu, Y., \& Tsai, T. 2007. Institutional entrepreneurship in building an environmental protection system for the People's Republic of China. Organization Studies, 28(7): 1013-1034.

Clemens, E. S. 1993. Organizational repertoires and institutional change: Women's groups and the transformation of U.S. politics, 1890-1920. American Journal of Sociology, 98(4): 755-798.

Clemens, E. S., \& Cook, J. M. 1999. Politics and institutionalism: Explaining durability and change. Annual Review of Sociology, 25: 441-466.

Colyvas, J. A., \& Jonsson, S. 2011. Ubiquity and legitimacy: Disentangling diffusion and institutionalization. Sociological Theory, 29(1): 27-53.

Compagni, A., Mele, V., \& Ravasi, D. 2015. How early implementations influence later adoptions of innovation: Social positioning and skill reproduction in the diffusion of robotic surgery. Academy of Management Journal, 58(1): 242-278.

Cooper, D. J., Ezzamel, M., \& Willmott, H. 2008. Examining “institutionalization”: A critical theoretic perspective. In R. Greenwood, C. Oliver, R. Suddaby, \& K. Sahlin (Eds.), The SAGE Handbook of Organizational Institutionalism: 673-701. London, U.K.: Sage.

Creed, W. D., Hudson, B. A., Okhuysen, G. A., \& Smith-Crowe, K. 2014. Swimming in a sea of shame: Incorporating emotion into explanations of institutional reproduction and change. Academy of Management Review, 39(3): 275-301.

Currie, G., Lockett, A., Finn, R., Martin, G., \& Waring, J. 2012. Institutional work to maintain professional power: Recreating the model of medical professionalism. Organization Studies, 33(7): 937-962.

Curtis, R. L., \& Zurcher, L. A. 1973. Stable resources of protest movements: The multiorganizational field. Social Forces, 52(1): 53-61.

Davis, G. F. 2013. After the corporation. Politics \& Society, 41(2): 283-308.

Deephouse, D. L. 1999. To be different, or to be the same? It's a question (and theory) of strategic balance. Strategic Management Journal, 20: 147-166. 
Delmestri, G. 2006. Streams of inconsistent institutional influences: Middle managers as carriers of multiple identities. Human Relations, 59(11): 1515-1541.

Dhalla, R., \& Oliver, C. 2013. Industry identity in an oligopolistic market and firms' responses to institutional pressures. Organization Studies, 34(12): 1803-1834.

Diani, M. 2013. Organizational fields and social movement dynamics. In J. van Stekelenburg, C. Roggeband, \& B. Klandermans (Eds.), The Future of Social Movement Research: Dynamics, Mechanisms, and Processes: 145-168. Minneapolis, MN: University of Minnesota Press.

Diani, M., \& Bison, I. 2004. Organizations, coalitions, and movements. Theory and Society, 33(3-4): 281-309.

Diani, M. \& K. Pilati 2011. Interests, identities, and relations: Drawing boundaries in civic organizational fields. Mobilization: An International Quarterly, 16(3): 265-282.

DiMaggio, P. J. 1991. Constructing an organizational field as a professional project: U.S. art museums, 1920-1940. W. W. Powell, \& P. J. DiMaggio (Eds.), The New

Institutionalism in Organizational Analysis: 267-292. Chicago: University of Chicago Press.

DiMaggio, P. J., \& Powell, W. W. 1983. The iron cage revisited: Institutional isomorphism and collective rationality in organizational fields. American Sociological Review, 48: 147160.

Djelic, M. L., \& Sahlin-Andersson, K. (Eds.). 2006. Transnational Governance: Institutional Dynamics of Regulation. Cambridge, U.K.: Cambridge University Press.

Dorado, S. 2005. Institutional entrepreneurship, partaking, and convening. Organization Studies, 26(3): 385-414.

Duffy, M. M., Binder, A. J., \& Skrentny, J. D. 2010. Elite status and social change: Using field analysis to explain policy formation and implementation. Social Problems, 57(1): 49-73.

Dunn, M. B., \& Jones, C. 2010. Institutional logics and institutional pluralism: The contestation of care and science logics in medical education, 1967-2005. Administrative Science Quarterly, 55(1): 114-149.

Evans, R., \& Kay, T. 2008. How environmentalists "greened" trade policy: Strategic action and the architecture of field overlap. American Sociological Review, 73: 970-991.

Farjoun, M. 2002. The dialectics of institutional development in emerging and turbulent fields: The history of pricing conventions in the on-line database industry. Academy of Management Journal, 45(5): 848-874.

Faulconbridge, J., \& Muzio, D. 2008. Organizational professionalism in globalizing law firms. Work, Employment \& Society, 22(1): 7-25.

Ferraris, A. 2014. Rethinking the literature on "multiple embeddedness" and subsidiary-specific advantages. Multinational Business Review, 22: 15-33.

Fiss, P. C. 2007. A set-theoretic approach to organizational configurations. Academy of Management Review, 32(4): 1180-1198.

Fligstein, N. 1990. The transformation of corporate capital. Cambridge, U.K.: Cambridge 
University Press.

Fligstein, N. 1991. The structural transformation of American industry: An institutional account of the causes of diversification in the largest firms, 1919-1979. In W. W. Powell, \& P. DiMaggio (Eds.), The new institutionalism in organizational analysis: 311 . Chicago: University of Chicago Press.

Fligstein, N. 1997. Social skill and institutional theory. American Behavioral Scientist, 40(4): $397-405$.

Fligstein, N. 2001. Social skill and the theory of fields. Sociological Theory, 19(2): 105-125.

Fligstein, N., \& Mara-Drita, I. 1996. How to make a market: Reflections on the attempt to create a single market in the European Union. American Journal of Sociology, 102(1): 1-33.

Fligstein, N., \& McAdam, D. 2012. A theory of fields. Oxford, U.K.: Oxford University Press.

Fligstein, N., \& McAdam, D. 2012. Toward a general theory of strategic action fields. Sociological Theory, 29: 1-26.

Freeman, J. H., \& Audia, P. G. 2006. Community ecology and the sociology of organizations. Annual Review of Sociology, 32: 145-169.

Friedland, R. 2014. Divine institution: Max Weber's value spheres and institutional theory. In P. Tracey, N. Phillips, \& M. Lounsbury (Eds.), Research in the sociology of organizations, vol. 41: 217-258. Bingley, U.K.: Emerald Group Publishing.

Friedland, R. \& Alford, R.R. 1991. Bringing society back in: Symbols, practices, and institutional contradictions. In W.W. Powell, P.J. DiMaggio (Eds.), The new institutionalism in organizational analysis: 232-263. Chicago: University of Chicago Press.

Furnari, S. 2014. Interstitial spaces: Microinteraction settings and the genesis of new practices between institutional fields. Academy of Management Review, 39(4): 439-462.

Furnari, S. 2016. Institutional fields as linked arenas: Inter-field resource dependence, institutional work and institutional change. Human Relations, 69(3): 551-580.

Galvin, T. L. 2002. Examining institutional change: Evidence from the founding dynamics of U.S. health care interest associations. Academy of Management Journal, 45(4): 673696.

Garud, R. 2008. Conferences as venues for the configuration of emerging organizational fields: The case of cochlear implants. Journal of Management Studies, 45(6): 1061-1088.

Garud, R., Jain, S., \& Kumaraswamy, A. 2002. Institutional entrepreneurship in the sponsorship of common technological standards: The case of Sun Microsystems and Java. Academy of Management Journal, 45(1): 196-214.

Garud, R., \& Karnoe, P. (Eds.). 2001. Path dependence and creation. New York: Psychology Press.

Gawer, A., \& Phillips, N. 2013. Institutional work as logics shift: The case of Intel's transformation to platform leader. Organization Studies, 34(8): 1035-1071.

George, G., Dahlander, L., Graffin, S., \& Sim, S. 2016. Reputation and status: Expanding the 
role of social evaluations in management research. Academy of Management Journal, 59(1): $1-13$.

Gibbons, D. E. 2004. Network structure and innovation ambiguity effects on diffusion in dynamic organizational fields. Academy of Management Journal, 47(6): 938-951.

Glynn, M. A. 2000. When cymbals become symbols: Conflict over organizational identity within a symphony orchestra. Organization Science, 11(3): 285-298.

Glynn, M. A. 2008. Configuring the field of play: How hosting the Olympic Games impacts civic community. Journal of Management Studies, 45(6): 1117-1146.

Glynn, M. A., \& Abzug, R. 2002. Institutionalizing identity: Symbolic isomorphism and organizational names. Academy of Management Journal, 45(1): 267-280.

Glynn, M. A., \& Lounsbury, M. 2005. From the critics' corner: Logic blending, discursive change and authenticity in a cultural production system. Journal of Management Studies, 42(5): 1031-1055.

Gomez, M. L., \& Bouty, I. 2011. The emergence of an influential practice: Food for thought. Organization Studies, 32(7): 921-940.

Goodrick, E., \& Reay, T. 2011. Constellations of institutional logics changes in the professional work of pharmacists. Work and Occupations, 38(3): 372-416.

Granqvist, N., \& Laurila, J. 2011. Rage against self-replicating machines: Framing science and fiction in the U.S. nanotechnology field. Organization Studies, 32(2): 253-280.

Gray, P. H., \& Cooper, W. H. 2010. Pursuing failure. Organizational Research Methods, 13 : $620-643$.

Greenwood, R., Díaz, A. M., Li, S. X., \& Lorente, J. C. 2010. The multiplicity of institutional logics and the heterogeneity of organizational responses. Organization Science, 21(2): 521-539.

Greenwood, R., \& Hinings, C. R. 1996. Understanding radical organizational change: Bringing together the old and the new institutionalism. Academy of Management Review, 21(4): $1022-1054$.

Greenwood, R., \& Hinings, C. R. 2006. Radical organizational change. In S. Clegg, C. Hardy, T. B. Lawrence, \& W. R. Nord (Eds.), The SAGE handbook of organization studies $2^{\text {nd }}$ ed.: 814-842. London, U.K.: Sage.

Greenwood, R., Hinings, C. R., \& Whetten, D. 2014. Rethinking institutions and organizations. Journal of Management Studies, 51(7): 1206-1220.

Greenwood, R., Oliver, C., Suddaby, R., \& Sahlin-Andersson, K. 2008. Introduction. In R. Greenwood, C. Oliver, R. Suddab, \& K. Sahlin-Andersson (Eds.), The SAGE handbook of organizational institutionalism: 1-46. London, U.K.: Sage.

Greenwood, R., Raynard, M., Kodeih, F., Micelotta, E. R., \& Lounsbury, M. 2011. Institutional complexity and organizational responses. Academy of Management Annals, 5: 317-371.

Greenwood, R., \& Suddaby, R. 2005. Rhetorical strategies of legitimacy. Administrative Science Quarterly, 50(1): 35-67. 
Greenwood, R., \& Suddaby, R. 2006. Institutional entrepreneurship in mature fields: The big five accounting firms. Academy of Management Journal, 49: 27-48.

Greenwood, R., Suddaby, R., \& Hinings, C. R. 2002. Theorizing change: The role of professional associations in the transformation of institutionalized fields. Academy of Management Journal, 45(1): 58-80.

Guillen, M. F. 1997. Scientific management's lost aesthetic: Architecture, organization, and the Taylorized beauty of the mechanical. Administrative Science Quarterly, 42(4): 682-715.

Gurses, K., \& Ozcan, P. 2015. Entrepreneurship in regulated markets: framing contests and collective action to introduce pay TV in the U.S. Academy of Management Journal, 58(6): 1709-1739.

Hannan, M. T., \& Freeman, J. 1977. The population ecology of organizations. American Journal of Sociology, 82(5): 929-964.

Hannan, M. T., \& Freeman, J. 1989. Organizational ecology. Cambridge, MA: Harvard University Press.

Hardy, C., \& Maguire, S. 2010. Discourse, field-configuring events, and change in organizations and institutional fields: Narratives of DDT and the Stockholm convention. Academy of Management Journal, 53(6): 1365-1392.

Hardy, C., \& Phillips, N. 1999. No joking matter: Discursive struggle in the Canadian refugee system. Organization Studies, 20(1): 1-24.

Hargadon, A. B., \& Douglas, Y. 2001. When innovations meet institutions: Edison and the design of the electric light. Administrative Science Quarterly, 46(3): 476-501.

Helfen, M. 2015. Institutionalizing precariousness? The politics of boundary work in legalizing agency work in Germany, 1949-2004. Organization Studies, 36(10): 1387-1422.

Helfen, M., \& Sydow, J. 2013. Negotiating as institutional work: The case of labour standards and international framework agreements. Organization Studies, 34(8): 1073-1098.

Helms, W.S., Oliver, C., \& Webb, K. 2012. Antecedents of settlement on a new institutional practice: Negotiation of the ISO 26000 standard on social responsibility. Academy of Management Journal, 55(5): 1120-1145.

Hensmans, M. 2003. Social movement organizations: A metaphor for strategic actors in institutional fields. Organization Studies, 24(3): 355-381.

Hinings, C. R., \& Greenwood, R. 1988. The tracks and dynamics of strategic change. Oxford, U.K.: Blackwell.

Hinings, C.R., Logue, D. \& Zietsma, C. (in press). Fields, governance and institutional infrastructure. In R. Greenwood, T. B. Lawrence, R. Meyer \& C. Oliver (Eds.), Handbook of organizational institutionalism (2 $2^{\text {nd }}$ ed.). Sage.

Hoffman, A. J. 1999. Institutional evolution and change: Environmentalism and the U.S. chemical industry. Academy of Management Journal, 42(4): 351-371.

Holland, L. L., \& Cable, S. 2002. Reconceptualizing social movement abeyance: The role of internal processes and culture in cycles of movement abeyance and resurgence. Sociological Focus, 35(3): 297-314. 
Holm, P. 1995. The dynamics of institutionalization: Transformation processes in Norwegian fisheries. Administrative Science Quarterly, 40(3): 398-422.

Ingenbleek, P., \& Reinders, M. J. 2013. The development of a market for sustainable coffee in the Netherlands: Rethinking the contribution of fair trade. Journal of Business Ethics, 113(3): 461-474.

Jay, J. 2013. Navigating paradox as a mechanism of change and innovation in hybrid organizations. Academy of Management Journal, 56(1): 137-159.

Jung, W., King, B. G., \& Soule, S. A. 2014. Issue bricolage: Explaining the configuration of the social movement sector, 1960-1995. American Journal of Sociology, 120(1): 187-225.

Kellogg, K. C. 2009. Operating room: Relational spaces and microinstitutional change in Surgery. American Journal of Sociology, 115(3): 657-711.

Kennedy, M. T., \& Fiss, P. C. 2009. Institutionalization, framing, and diffusion: The logic of TQM adoption and implementation decisions among U.S. hospitals. Academy of Management Journal, 52(5): 897-918.

Kim, T. Y., Shin, D., Oh, H., \& Jeong, Y. C. 2007. Inside the iron cage: Organizational political dynamics and institutional changes in presidential selection systems in Korean universities, 1985-2002. Administrative Science Quarterly, 52(2): 286-323.

Kipping, M., \& Kirkpatrick, I. 2013. Alternative pathways of change in professional services firms: The case of management consulting. Journal of Management Studies, 50(5): 777-807.

Kitchener, M. 2002. Mobilizing the logic of managerialism in professional fields: The case of academic health centre mergers. Organization Studies, 23(3): 391-420.

Kostova, T., Roth, K., \& Dacin, M. T. 2008. Institutional theory in the study of multinational corporations: A critique and new directions. Academy of Management Review, 33(4): 994-1006.

Kraatz, M.S. \& Block, E. 2008. Organizational implications of institutional pluralism. In R. Greenwood, C. Oliver, K. Sahlin, \& R. Suddaby (Eds.), The SAGE Handbook of Organizational Institutionalism: 243-275. Thousand Oaks, CA: Sage.

Lægreid, P., \& Serigstad, S. 2006. Framing the field of homeland security: The case of Norway. Journal of Management Studies, 43(6): 1395-1413.

Lampel, J., \& Meyer, A. D. 2008. Guest editors' introduction. Journal of Management Studies, 45(6): 1025-1035.

Lawrence, T. B., Amis, J. M., Munir, K., Hirsch, P., \& McGahan, A. 2014. Inequality, institutions, and organizations. Organization Studies, 35(10): 1553-1558.

Lawrence, T. B., Hardy, C., \& Phillips, N. 2002. Institutional effects of interorganizational collaboration: The emergence of proto-institutions. Academy of Management Journal, 45(1): 281-290.

Lawrence, T. B. \& Suddaby, R. 2006. Institutions and institutional work. In S. R. Clegg, C. Hardy, T. B. Lawrence, and W. R. Nord (Eds.), Handbook of organization studies (2nd ed.): 215-254. London, U.K.: Sage. 
Lawrence, T. B., Suddaby, R., \& Leca, B. (Eds.). 2009. Institutional work: Actors and agency in institutional studies of organizations. Cambridge, U.K.: Cambridge University Press.

Leblebici, H., Salancik, G. R., Copay, A., \& King, T. 1991. Institutional change and the transformation of interorganizational fields: An organizational history of the U.S. radio broadcasting industry. Administrative Science Quarterly, 36(3): 333-36.

Lee, M. D. P., \& Lounsbury, M. 2015. Filtering institutional logics: Community logic variation and differential responses to the institutional complexity of toxic waste. Organization Science: 26(3): 847-866.

Lepoutre, J. M., \& Valente, M. 2012. Fools breaking out: The role of symbolic and material immunity in explaining institutional nonconformity. Academy of Management Journal, 55(2): 285-313.

Leung, A., Zietsma, C. \& Peredo, A. M. 2014. Revolution of the middle-class housewives: Identity work as a process for embedded change. Organization Studies, 35(3): 423-450.

Levy, D., \& Scully, M. 2007. The institutional entrepreneur as modern prince: The strategic face of power in contested fields. Organization Studies, 28(7): 971-991.

Liu, S., \& Emirbayer, M. 2016. Field and ecology. Sociological Theory, 34(1): 62-79.

Logue, D. M., \& Clegg, S. R. 2015. WikiLeaks and the news of the world: The political circuitry of labelling. Journal of Management Inquiry, 24(4): 394-404.

Lounsbury, M. 2001. Institutional sources of practice variation: Staffing college and university recycling programs. Administrative Science Quarterly, 46: 29-56.

Lounsbury, M. 2007. A tale of two cities: Competing logics and practice variation in the professionalizing of mutual funds. Academy of Management Journal, 50(2): 289-307.

Maguire, S., \& Hardy, C. 2009. Discourse and deinstitutionalization: The decline of DDT. Academy of Management Journal, 52(1): 148-178.

Maguire, S., Hardy, C., \& Lawrence, T. B. 2004. Institutional entrepreneurship in emerging fields: HIV/AIDS treatment advocacy in Canada. Academy of Management Journal, 47(5): 657-679.

Mair, J., Martí, I., \& Ventresca, M. J. 2012. Building inclusive markets in rural Bangladesh: How intermediaries work institutional voids. Academy of Management Journal, 55(4): 819-850.

Marano, V., \& Kostova, T. 2016. Unpacking the institutional complexity in adoption of CSR practices in multinational enterprises. Journal of Management Studies, 52(1): 28-54.

Marcus, A. A., \& Anderson, M. H. 2010. Commitment to an emerging organizational field: An enactment theory. Business \& Society, 52(2): 181-212.

Marquis, C., Glynn, M. A., \& Davis, G. F. 2007. Community isomorphism and corporate social action. Academy of Management Review, 32(3): 925-945.

Marquis, C., \& Lounsbury, M. 2007. Vive la résistance: Competing logics and the consolidation of U.S. community banking. Academy of Management Journal, 50(4): 799-820. 
Mazza, C., \& Pedersen, J. S. 2004. From press to e-media? The transformation of an organizational field. Organization Studies, 25(6): 875-896.

McAdam, D., \& Scott, W. R. 2005. Organizations and movements. Social movements and organization theory: 4-40. Cambridge, U.K.: Cambridge University Press.

McCarthy, J. D., \& Zald, M. N. 1977. Resource mobilization and social movements: A partial theory. American Journal of Sociology, 82(6): 1212-1241.

McInerney, P. B. 2008. Showdown at Kykuit: Field-configuring events as loci for conventionalizing accounts. Journal of Management Studies, 45(6): 1089-1116.

Medvetz, T. 2012. Murky power: "Think tanks" as boundary organizations. Research in the Sociology of Organizations, 34: 113-133.

Meyer, A. D., Gaba, V., \& Colwell, K. A. 2005. Organizing far from equilibrium: Nonlinear change in organizational fields. Organization Science, 16(5): 456-473.

Meyer, R. E., Höllerer, M. A. 2010. Meaning structures in a contested issue field: A topographical map of shareholder value in Austria. Academy of Management Journal, 53(6): 1241-1262.

Meyer, K. E., Mudambi, R., \& Narula, R. 2011. Multinational enterprises and local contexts: The opportunities and challenges of multiple embeddedness. Journal of Management Studies, 48(2): 235-252.

Meyer, J., Scott, W. R., \& Strang, D. 1987. Centralization, fragmentation, and school district complexity. Administrative Science Quarterly, 32(2): 186-201.

Meyer, A. D., Tsui, A. S., \& Hinings, C. R. 1993. Configurational approaches to organizational analysis. Academy of Management Journal, 36(6): 1175-1195.

Meznar, M. B., \& Nigh, D. 1995. Buffer or bridge? Environmental and organizational determinants of public affairs activities in American firms. Academy of Management Journal, 38(4): 975-996.

Micelotta, T. 2007. How foundations shape social movements: The construction of an organizational field and the rise of forest certification. Social Problems, 54(3): 229-255.

Mizruchi, M. S., \& Fein, L. C. 1999. The social construction of organizational knowledge: A study of the uses of coercive, mimetic, and normative isomorphism. Administrative Science Quarterly, 44(4): 653-683.

Morrill, C., Zald, M. N., \& Rao, H. 2003. Covert political conflict in organizations: Challenges from below. Annual Review of Sociology, 29: 391-415.

Munir, K. A. 2005. The social construction of events: A study of institutional change in the photographic field. Organization Studies, 26(1): 93-112.

Munir, K. A., \& Phillips, N. 2005. The birth of the 'Kodak moment': Institutional entrepreneurship and the adoption of new technologies. Organization Studies, 26(11): 1665-1687.

Murray, F. 2010. The oncomouse that roared: hybrid exchange strategies as a source of distinction at the boundary of overlapping institutions. American Journal of Sociology, 116(2): 341-388. 
Murray, F., \& O'Mahony, S. 2007. Exploring the foundations of cumulative innovation: Implications for organization science. Organization Science, 18(6): 1006-1021.

Nigam, A., \& Ocasio, W. 2010. Event attention, environmental sensemaking, and change in institutional logics: An inductive analysis of the effects of public attention to Clinton's health care reform initiative. Organization Science, 21(4): 823-841.

Oakes, L. S., Townley, B., \& Cooper, D. J. 1998. Business planning as pedagogy: Language and control in a changing institutional field. Administrative Science Quarterly, 43(2): 257292.

Oliver, C. 1992. The antecedents of deinstitutionalization. Organization Studies, 13(4): 563588.

Oliver, A. L., \& Montgomery, K. 2008. Using field-configuring events for sense-making: A cognitive network approach. Journal of Management Studies, 45(6): 1147-1167.

O’Mahony, S., \& Bechky, B. A. 2008. Boundary organizations: Enabling collaboration among unexpected allies. Administrative Science Quarterly, 53(3): 422-459.

Orsato, R. J., den Hond, F., \& Clegg, S. R. 2002. The political ecology of automobile recycling in Europe. Organization Studies, 23(4): 639-665.

O’Sullivan, N., \& O’Dwyer, B. 2015. The structuration of issue-based fields: Social accountability, social movements and the Equator Principles issue-based field. Accounting, Organizations and Society, 43: 33-55.

Pache, A. C., \& Santos, F. 2010. When worlds collide: The internal dynamics of organizational responses to conflicting institutional demands. Academy of Management Review, 35(3): $455-476$.

Patvardhan, S. D., Gioia, D. A., \& Hamilton, A. L. 2015. Weathering a meta-level identity crisis: Forging a coherent collective identity for an emerging field. Academy of Management Journal, 58(2): 405-435.

Pettigrew, A. M., \& Whipp, R. 1993. Managing change for competitive success. Oxford, U.K.: Wiley-Blackwell.

Pettigrew, A. M., Woodman, R. W., \& Cameron, K. S. 2001. Studying organizational change and development: Challenges for future research. Academy of Management Journal, 44(4): 697-713.

Pfeffer, J., \& Salancik, G. R. 1978. The external control of organizations: A resource dependent approach. New York: Harper and Row Publishers.

Phillips, N., Lawrence, T. B., \& Hardy, C. 2000. Inter-organizational collaboration and the dynamics of institutional fields. Journal of Management Studies, 37(1): 23-43.

Porac, J. F., Thomas, H., \& Baden-Fuller, C. 1989. Competitive groups as cognitive communities: The case of Scottish knitwear manufacturers. Journal of Management studies, 26(4): 397-416.

Porac, J. F., Thomas, H., \& Baden-Fuller, C. 2011. Competitive groups as cognitive communities: the case of Scottish knitwear manufacturers revisited. Journal of Management Studies, 48(3): 646-664. 
Porter, M. E. 1980. Competitive strategy: Techniques for analyzing industries and competitors. New York: Free Press.

Powell, W.W., Oberg, A., Korff, V.P., Oelberger, C., \& Kloos, K. (in press). Institutional analysis in a digital era: Mechanisms and methods to understand emerging fields. In G. Krücken, C. Mazza, R. Meyer, \& P. Walgenbach (Eds.), New themes in institutional analysis: Topics and issues from European research. Cheltenham, U.K.: Edward Elgar.

Powell, W. W., \& Sandholtz, K. W. 2012. Amphibious entrepreneurs and the emergence of organizational forms. Strategic Entrepreneurship Journal, 6(2): 94-115.

Purdy, J. M., \& Gray, B. 2009. Conflicting logics, mechanisms of diffusion, and multilevel dynamics in emerging institutional fields. Academy of Management Journal, 52(2): $355-380$.

Quirke, L. 2013. Rogue resistance: Sidestepping isomorphic pressures in a patchy institutional field. Organization Studies, 34(11): 1675-1699.

Raaijmakers, A. G., Vermeulen, P. A., Meeus, M. T., \& Zietsma, C. 2015. I need time! Exploring pathways to compliance under institutional complexity. Academy of Management Journal, 58(1): 85-110.

Rao, H., Morrill, C., \& Zald, M. N. 2000. Power plays: How social movements and collective action create new organizational forms. Research in Organizational Behavior, 22: 237281.

Raynard, M. (in press). Deconstructing complexity: Configurations of institutional complexity and structural hybridity. Strategic Organization.

Reay, T., Golden-Biddle, K., \& Germann, K. 2006. Legitimizing a new role: Small wins and microprocesses of change. Academy of Management Journal, 49(5): 977-998.

Reay, T., \& Hinings, C. R. 2005. The recomposition of an organizational field: Health care in Alberta. Organization Studies, 26(3): 351-384

Reay, T., \& Hinings, C. R. 2009. Managing the rivalry of competing institutional logics. Organization Studies, 30(6): 629-652.

Reinecke, J., Manning, S., \& von Hagen, O. 2012. The emergence of a standards market: Multiplicity of sustainability standards in the global coffee industry. Organization Studies, 33: 791-814.

Rittel, H. W., \& Webber, M. M. 1973. Dilemmas in a general theory of planning. Policy Sciences, 4(2): 155-169.

Sauder, M. 2008. Interlopers and field change: The entry of U.S. News into the field of legal education. Administrative Science Quarterly, 53(2): 209-234.

Sawyers, T. M., \& Meyer, D. S. 1999. Missed opportunities: Social movement abeyance and public policy. Social Problems, 46(2): 187-206.

Schüssler, E., Rüling, C. C., \& Wittneben, B. B. F. 2014. On melting summits: The limitations of field-configuring events as catalysts of change in transnational climate policy. Academy of Management Journals, 57(1): 140-171.

Scott, W. R. 1995. Institutions and Organizations. Thousand Oaks, CA: Sage. 
Scott, W. R. 2001. Institutions and Organizations (2nd ed.). Thousand Oaks, CA: Sage.

Scott, W. R. 2014. Institutions and Organizations (4th ed.). Thousand Oaks, CA: Sage.

Scott, W. R., Ruef, M., Mendel, P., \& Caronna, C. A. 2000. Institutional change and organizations: From professional dominance to managed care. Chicago: University of Chicago Press.

Seo, M. G., \& Creed, W. D. 2002. Institutional contradictions, praxis, and institutional change: A dialectical perspective. Academy of Management Review, 27(2): 222-247.

Sewell, W. 1992. A theory of structure: Duality, agency and transformation. American Journal of Sociology, 98: 1-29.

Sherer, P. D., \& Lee, K. 2002. Institutional change in large law firms: A resource dependency and institutional perspective. Academy of Management Journal, 45(1): 102-119.

Sine, W. D., \& Lee, B. H. 2009. Tilting at windmills? The environmental movement and the emergence of the U.S. wind energy sector. Administrative Science Quarterly, 54(1): $123-155$.

Smets, M., Morris, T. I. M., \& Greenwood, R. 2012. From practice to field: A multilevel model of practice-driven institutional change. Academy of Management Journal, 55(4): 877904.

Stone, M. M., \& Sandfort, J. R. 2009. Building a policy fields framework to inform research on nonprofit organizations. Nonprofit and Voluntary Sector Quarterly, 38(6): 1054-1075.

Suddaby, R., \& Greenwood, R. 2005. Rhetorical strategies of legitimacy. Administrative Science Quarterly, 50(1): 35-67.

Suddaby, R., \& Muzio, D. 2015. Theoretical perspectives on the professions. In L. Empson, D. Muzio, J. Broschak, \& R. Hinings (Eds.), The Oxford handbook of professional service firms: 25-47. Oxford, U.K.: Oxford University Press.

Swan, J., Bresnen, M., Robertson, M., Newell, S., \& Dopson, S. 2010. When policy meets practice: Colliding logics and the challenges of 'Mode 2'initiatives in the translation of academic knowledge. Organization Studies, 31(9-10): 1311-1340.

Sydow, J., Windeler, A., Schubert, C., \& Mollering, G. 2012. Organizing R\&D consortia for path creation and extension: The case of semiconductor manufacturing technologies. Organization Studies, 33(7): 907-936

Taylor, V. 1989. Social movement continuity: The women's movement in abeyance. American Sociological Review, 54(5): 761-775.

Thornton, P. H., Ocasio, W., \& Lounsbury, M. 2012. The institutional logics perspective: A new approach to culture, structure, and process. Oxford, U.K.: Oxford University Press.

Tihanyi, L., \& Hegarty, W. H. 2007. Political interests and the emergence of commercial banking in transition economies. Journal of Management Studies, 44(5): 788-813.

Tolbert, P. S., \& Zucker, L. G. 1983. Institutional sources of change in the formal structure of organizations: The diffusion of civil service reform, 1880-1935. Administrative Science Quarterly, 28: 22-39. 
Vaccaro, A., \& Palazzo, G. 2015. Values against violence: Institutional change in societies dominated by organized crime. Academy of Management Journal, 58(4): 1075-1101.

van Bommel, K., \& Spicer, A. 2011. Hail the snail: Hegemonic struggles in the Slow Food movement. Organization Studies, 32(12): 1717-1744.

Van De Ven, A. H., \& Poole, M. S. 1995. Explaining development and change in organizations. Academy of Management Review, 20(3): 510-540.

van Gestel, N., \& Hillebrand, B. 2011. Explaining stability and change: The rise and fall of logics in pluralistic fields. Organization Studies, 32(2): 231-252.

van Wijk, J., Stam, W., Elfring, T., Zietsma, C., \& den Hond, F. 2013. Activists and incumbents structuring change: The interplay of agency, culture, and networks in field evolution. Academy of Management Journal, 56(2): 358-386.

Vermeulen, P., Buch, R., \& Greenwood, R. 2007. The impact of governmental policies in institutional fields: The case of innovation in the Dutch concrete industry. Organization Studies, 28(4): 515-540.

Voronov, M., De Clerq, D., \& Hinings, C. R. 2013. Conformity and distinctiveness in a global institutional framework: The legitimation of Ontario fine wine. Journal of Management Studies, 50(4): 607-645.

Voronov, M., \& Vince, R. 2012. Integrating emotions into the analysis of institutional work. Academy of Management Review, 37(1): 58-81.

Wacquant, L. J. 1989. A workshop with Pierre Bourdieu. Sociological Theory, 7(1): 26-63.

Washington, M. 2004. Field approaches to institutional change: The evolution of the National Collegiate Athletic Association 1906-1995. Organization Studies, 25(3): 393-414.

Weber, K., Heinz, K. L., \& DeSoucey, M. 2008. Forage for thought: Mobilizing codes in the movement for grass-fed meat and dairy products. Administrative Science Quarterly, 53(3): 529-567.

Wijen, F., \& Ansari, S. 2007. Overcoming inaction through collective institutional entrepreneurship: Insights from regime theory. Organization studies, 28(7): 1079-1100.

Windeler, A., \& Sydow, J. 2001. Project networks and changing industry practices collaborative content production in the German television industry. Organization Studies, 22(6): 1035-1060.

Wooten, M., \& Hoffman, A. J. 2008. Organizational fields: Past, present and future. In R. Greenwood, C. Oliver, K. Sahlin-Andersson, \& R. Suddaby (Eds.), SAGE handbook of organizational institutionalism: 130-147. London, U.K.: Sage.

Wright, C., Nyberg, D., \& Grant, D. 2012. "Hippies on the third floor”: Climate change, narrative identity and the micro-politics of corporate environmentalism. Organization Studies, 33(11): 1451-1475.

Wright, A. L., \& Zammuto, R. F. 2013. Wielding the willow: Processes of institutional change in English county cricket. Academy of Management Journal, 56(1): 308-330.

Yoshikawa, T., Tsui-Auch, L. S., \& McGuire, J. 2007. Corporate governance reform as institutional innovation: The case of Japan. Organization Science, 18(6): 973-988. 
Zbaracki, M. J. 1998. The rhetoric and reality of total quality management. Administrative Science Quarterly, 43(3): 602-636.

Zietsma, C., \& Lawrence, T. B. 2010. Institutional work in the transformation of an organizational field: The interplay of boundary work and practice work. Administrative Science Quarterly, 55(2): 189-221.

Zietsma, C., \& McKnight, B. 2009. Building the iron cage: Institutional creation work in the context of competing protoinstitutions. In Lawrence, T. B., Suddaby, R. \& Leca, B. (Eds.), Institutional work: Actors and agency in institutional studies of organizations: 143-177. Cambridge, U.K.: Cambridge University Press.

Zilber, T. B. 2002. Institutionalization as an interplay between actions, meanings, and actors: The case of a rape crisis center in Israel. Academy of Management Journal, 45(1): 234 254.

Zilber, T. B. 2006. The work of the symbolic in institutional processes: Translations of rational myths in Israeli high-tech. Academy of Management Journal, 49(2): 281-303.

Zilber, T. B. 2007. Stories and the discursive dynamics of institutional entrepreneurship: The case of Israeli high-tech after the bubble. Organization Studies, 28(7): 1035-1054. 
Table 1. Types of Fields and their Characteristics

\begin{tabular}{|c|c|c|c|c|c|c|}
\hline & \multicolumn{3}{|c|}{ Exchange Fields } & \multicolumn{3}{|c|}{ Issue Fields } \\
\hline & $\begin{array}{c}\text { Industry } \\
\text { Exchange Fields }\end{array}$ & $\begin{array}{c}\text { Professional } \\
\text { Exchange Fields }\end{array}$ & $\begin{array}{l}\text { Social Movement } \\
\text { Exchange Fields }\end{array}$ & $\begin{array}{l}\text { Competitive } \\
\text { Issue Fields }\end{array}$ & $\begin{array}{l}\text { Interstitial } \\
\text { Issue Fields }\end{array}$ & $\begin{array}{l}\text { Bridging } \\
\text { Issue Fields }\end{array}$ \\
\hline $\begin{array}{l}\text { Purpose/Focus } \\
\text { of Orchestration }\end{array}$ & $\begin{array}{l}\text { Coordinating exchange } \\
\text { with interaction partners; } \\
\text { coordinating lobbying, } \\
\text { industry promotion or } \\
\text { standards development. }\end{array}$ & $\begin{array}{l}\text { Controlling } \\
\text { practices and } \\
\text { enforcing } \\
\text { boundaries. }\end{array}$ & $\begin{array}{l}\text { Mobilizing and } \\
\text { coordinating actors } \\
\text { and resources to } \\
\text { further an agenda or } \\
\text { extend an ideology. }\end{array}$ & $\begin{array}{l}\text { Competing over } \\
\text { meanings and } \\
\text { practices. }\end{array}$ & $\begin{array}{l}\text { Negotiating } \\
\text { coordination to } \\
\text { respond to } \\
\text { emerging issues } \\
\text { or opportunities. }\end{array}$ & $\begin{array}{l}\text { Governing common } \\
\text { resources or shared } \\
\text { issues. }\end{array}$ \\
\hline Boundaries & $\begin{array}{l}\text { Boundaries tend to be } \\
\text { relatively permeable to } \\
\text { new entrants and based on } \\
\text { practices. }\end{array}$ & $\begin{array}{l}\text { Boundaries are } \\
\text { strong and policed, } \\
\text { with legal and } \\
\text { educational entry } \\
\text { barriers. } \\
\end{array}$ & $\begin{array}{l}\text { Boundaries are } \\
\text { typically highly } \\
\text { permeable and based } \\
\text { on ideology. }\end{array}$ & $\begin{array}{l}\text { Boundaries are } \\
\text { contested to } \\
\text { challenge } \\
\text { practices and } \\
\text { jurisdictions. } \\
\end{array}$ & $\begin{array}{l}\text { Boundaries are } \\
\text { highly permeable } \\
\text { and based on } \\
\text { interest. }\end{array}$ & $\begin{array}{l}\text { Boundaries are } \\
\text { formalized, and often } \\
\text { managed by a } \\
\text { boundary } \\
\text { organization. } \\
\end{array}$ \\
\hline Constituents & $\begin{array}{l}\text { Focal industry population } \\
\text { and its interaction } \\
\text { partners. }\end{array}$ & \begin{tabular}{|l} 
Focal professional \\
population and its \\
interaction partners.
\end{tabular} & $\begin{array}{l}\text { Focal social } \\
\text { movement population } \\
\text { and its funders, } \\
\text { supporters, etc. }\end{array}$ & $\begin{array}{l}\text { Two or more } \\
\text { populations } \\
\text { competing for } \\
\text { dominance on an } \\
\text { issue. }\end{array}$ & $\begin{array}{l}\text { Individual } \\
\text { members of } \\
\text { multiple fields } \\
\text { who share an } \\
\text { interest in a new } \\
\text { issue or } \\
\text { opportunity. } \\
\end{array}$ & $\begin{array}{l}\text { Representatives of } \\
\text { two or more } \\
\text { interacting fields or } \\
\text { groups and a } \\
\text { boundary } \\
\text { organization or } \\
\text { arbiter. } \\
\end{array}$ \\
\hline $\begin{array}{l}\text { Relational } \\
\text { Structure }\end{array}$ & $\begin{array}{l}\text { Elite and core/periphery } \\
\text { structure often exists, } \\
\text { usually associated with } \\
\text { market share. }\end{array}$ & $\begin{array}{l}\text { Gatekeeper and } \\
\text { hierarchical } \\
\text { structure usually } \\
\text { exists. }\end{array}$ & $\begin{array}{l}\text { Egalitarian with } \\
\text { networks in clusters } \\
\text { and collaborations } \\
\text { among networks. }\end{array}$ & $\begin{array}{l}\text { Competing } \\
\text { populations. }\end{array}$ & $\begin{array}{l}\text { Disparate groups } \\
\text { may form } \\
\text { alliances. }\end{array}$ & $\begin{array}{l}\text { Boundary } \\
\text { organization bridges } \\
\text { diverse groups. }\end{array}$ \\
\hline Logics & $\begin{array}{l}\text { Multiple, often segmented } \\
\text { logic permutations. }\end{array}$ & Single/few. & Single/few. & $\begin{array}{l}\text { Multiple, } \\
\text { competing. }\end{array}$ & $\begin{array}{l}\text { Multiple, } \\
\text { fragmented. }\end{array}$ & $\begin{array}{l}\text { Multiple, blended at } \\
\text { interaction point. }\end{array}$ \\
\hline Identity & $\begin{array}{l}\text { Variations exist based on } \\
\text { competitive positioning. }\end{array}$ & $\begin{array}{l}\text { Shared - Based on } \\
\text { education, practices } \\
\text { and values. }\end{array}$ & $\begin{array}{l}\text { Shared — Based on } \\
\text { shared ideology, with } \\
\text { variations. }\end{array}$ & $\begin{array}{l}\text { Heterogeneous } \\
\text { between and } \\
\text { homogeneous } \\
\text { within } \\
\text { populations. } \\
\end{array}$ & $\begin{array}{l}\text { Identity is } \\
\text { emerging. }\end{array}$ & $\begin{array}{l}\text { Heterogeneous } \\
\text { identities. }\end{array}$ \\
\hline $\begin{array}{l}\text { Implications for } \\
\text { Isomorphism } \\
\text { and Diffusion }\end{array}$ & $\begin{array}{l}\text { Isomorphic pressures are } \\
\text { moderate and come } \\
\text { primarily from exchange } \\
\text { partners. Innovations } \\
\text { occur frequently and } \\
\text { diffuse rapidly. }\end{array}$ & \begin{tabular}{|l|} 
Isomorphic \\
pressures are strong \\
from professional \\
association. \\
Innovations are \\
resisted, but diffuse \\
when endorsed. \\
\end{tabular} & $\begin{array}{l}\text { Isomorphic pressures } \\
\text { are based on } \\
\text { adherence to ideology } \\
\text { more than practices. } \\
\text { Diffusion is likely to } \\
\text { be spotty, with } \\
\text { significant variation. }\end{array}$ & $\begin{array}{l}\text { Isomorphic and } \\
\text { diffusion } \\
\text { pressures are } \\
\text { contradictory. }\end{array}$ & $\begin{array}{l}\text { Isomorphic } \\
\text { pressures are } \\
\text { weak and } \\
\text { diffusion is } \\
\text { uncertain. }\end{array}$ & $\begin{array}{l}\text { Isomorphic pressures } \\
\text { and diffusion depend } \\
\text { on the governance } \\
\text { organization or } \\
\text { agreement among } \\
\text { parties. }\end{array}$ \\
\hline
\end{tabular}


Table 2: Field Conditions

\begin{tabular}{|l|l|l|}
\hline & Settled Logic Prioritizations & Unsettled Logic Prioritizations \\
\hline $\begin{array}{l}\text { Limited Institutional } \\
\text { Infrastructure (Weakly }\end{array}$ & Aligned/Aligning & Fragmented \\
\hline $\begin{array}{l}\text { Elaborated Institutional } \\
\text { Infrastructure (Highly } \\
\text { Institutionalized) }\end{array}$ & Established & Contested \\
\hline
\end{tabular}


Table 3. Types of Fields and Change

\begin{tabular}{|c|c|c|c|c|c|c|}
\hline & \multicolumn{3}{|c|}{ Exchange Fields } & \multicolumn{3}{|c|}{ Issue Fields } \\
\hline & $\begin{array}{c}\text { Industry } \\
\text { Exchange Fields }\end{array}$ & $\begin{array}{c}\text { Professional } \\
\text { Exchange Fields }\end{array}$ & $\begin{array}{l}\text { Social Movement } \\
\text { Exchange Fields }\end{array}$ & $\begin{array}{l}\text { Competitive } \\
\text { Issue Fields }\end{array}$ & $\begin{array}{c}\text { Interstitial } \\
\text { Issue Fields }\end{array}$ & $\begin{array}{c}\text { Bridging } \\
\text { Issue Fields }\end{array}$ \\
\hline Scope & $\begin{array}{l}\text { Convergent to Radical } \\
\text { (but disguised) }\end{array}$ & $\begin{array}{l}\text { Primarily } \\
\text { Convergent }\end{array}$ & Convergent to Radical & $\begin{array}{l}\text { Convergent to } \\
\text { Radical }\end{array}$ & Radical & $\begin{array}{l}\text { Primarily } \\
\text { Convergent }\end{array}$ \\
\hline Pace & $\begin{array}{l}\text { Fast to change, moderate } \\
\text { and spotty diffusion }\end{array}$ & $\begin{array}{l}\text { Slow to change } \\
\text { (unless legislated), } \\
\text { rapid diffusion }\end{array}$ & $\begin{array}{l}\text { Fast to change, } \\
\text { moderate and spotty } \\
\text { diffusion }\end{array}$ & Slow to change & $\begin{array}{l}\text { Many changes emerge } \\
\text { quickly, spotty diffusion }\end{array}$ & $\begin{array}{l}\text { Slow to change, } \\
\text { rapid diffusion }\end{array}$ \\
\hline Linearity & Mostly linear & $\begin{array}{l}\text { Nonlinear until } \\
\text { change is accepted, } \\
\text { then diffusion is } \\
\text { linear }\end{array}$ & Nonlinear & Nonlinear & Nonlinear & $\begin{array}{l}\text { Nonlinear until } \\
\text { change is } \\
\text { accepted, then } \\
\text { diffusion is linear }\end{array}$ \\
\hline $\begin{array}{l}\text { Sample } \\
\text { Studies }\end{array}$ & $\begin{array}{l}\text { Anand \& Jones, 2008; } \\
\text { Anand \& Watson, 2004; } \\
\text { Anand \& Peterson, 2000; } \\
\text { Ansari \& Phillips, 2011; } \\
\text { Gawer \& Phillips, 2013; } \\
\text { Lepoutre \& Valente, 2012 }\end{array}$ & $\begin{array}{l}\text { Castel \& Friedberg, } \\
\text { 2010; Currie et al., } \\
\text { 2012; Greenwood, } \\
\text { Suddaby, \& } \\
\text { Hinings, 2002; } \\
\text { Smets et al., 2012; } \\
\text { Suddaby \& } \\
\text { Greenwood, } 2005\end{array}$ & $\begin{array}{l}\text { Hardy \& Maguire, } \\
\text { 2010; van Bommel \& } \\
\text { Spicer, } 2013\end{array}$ & $\begin{array}{l}\text { Gurses \& Ozcan, } \\
\text { 2015; Hardy \& } \\
\text { Phillips, 1999; } \\
\text { Hoffman, 1999; } \\
\text { Meyer \& Höllerer, } \\
\text { 2010; Zietsma \& } \\
\text { Lawrence, } 2010\end{array}$ & $\begin{array}{l}\text { Akemu, Whiteman, \& } \\
\text { Kennedy, 2006; } \\
\text { Furnari, 2014; } \\
\text { Granqvist \& Laurila, } \\
\text { 2011; Maguire, } \\
\text { Lawrence, \& Hardy, } \\
\text { 2004; Powell \& } \\
\text { Sandholtz, 2012; Purdy } \\
\text { \& Gray, 2010 }\end{array}$ & $\begin{array}{l}\text { Child, Lu, \& Tsai, } \\
\text { 2007; Helfen \& } \\
\text { Sydow, 2013; } \\
\text { Helms et al., 2013; } \\
\text { O’Mahoney \& } \\
\text { Bechky, } 2008\end{array}$ \\
\hline
\end{tabular}


Table 4. Field Conditions and Pathways of Change

\begin{tabular}{|c|c|c|c|c|}
\hline $\begin{array}{l}\text { Pathway: } \\
\text { Condition } \\
\text { to } \\
\text { Condition }\end{array}$ & $\begin{array}{l}\text { Likely } \\
\text { Direction } \\
\text { of Field } \\
\text { Change }\end{array}$ & Description of Pathway & Common Triggers & $\begin{array}{l}\text { Sample Studies That } \\
\text { Include This Move }\end{array}$ \\
\hline $\begin{array}{l}\text { Established } \\
\text { to } \\
\text { (re)aligning }\end{array}$ & Diverging & $\begin{array}{l}\text { Field changes incrementally, } \\
\text { with incumbents and elites } \\
\text { managing the extent of the } \\
\text { divergence. May be } \\
\text { realignment of relational } \\
\text { channels or field boundaries } \\
\text { rather than challenging field } \\
\text { position. Introduction of new } \\
\text { actor, new technology or new } \\
\text { law requires a } \\
\text { response/realignment of field. }\end{array}$ & $\begin{array}{l}\text { FCE, new technology, } \\
\text { logics give space for } \\
\text { innovation, internals } \\
\text { creating sub fields }\end{array}$ & $\begin{array}{l}\text { Anand \& Jones (2008); } \\
\text { Anand \& Watson } \\
\text { (2004); Ansari \& } \\
\text { Phillips (2010); Gawer } \\
\text { \& Phillips (2013); } \\
\text { Guillen (1997); } \\
\text { Lepoutre \& Valente } \\
\text { (2012); Nigam \& } \\
\text { Ocasio (2010); Oakes, } \\
\text { Townley, \& Cooper } \\
\text { (1998) }\end{array}$ \\
\hline $\begin{array}{l}\text { Established } \\
\text { to contested }\end{array}$ & Diverging & $\begin{array}{l}\text { Field is disrupted, field } \\
\text { positions and rules of the game } \\
\text { are challenged; legitimacy of } \\
\text { positions and rules are } \\
\text { questioned. Introduction of new } \\
\text { actor, new technology or new } \\
\text { law disrupts status quo. Rules } \\
\text { are up for grabs. }\end{array}$ & $\begin{array}{l}\text { Common when the } \\
\text { State imposes new } \\
\text { rule/regulation; } \\
\text { peripheral tech enters } \\
\text { field, peripheral SMO, } \\
\text { peripheral actor, } \\
\text { peripheral actor } \\
\text { changes rules, new } \\
\text { actor/new rankings } \\
\text { (legitimacy from } \\
\text { societal field) }\end{array}$ & $\begin{array}{l}\text { Anand \& Peterson } \\
\text { (2000); Borum (2004); } \\
\text { Castle \& Friedberg } \\
\text { (2001); Child, Lui, \& } \\
\text { Tsai (2007); Currie, } \\
\text { Locke, Finn, Martin, \& } \\
\text { Waring (2010); Glynn } \\
\text { (2008); Haragdon \& } \\
\text { Douglas (2001); } \\
\text { Hensmans (2003); } \\
\text { Sauder (2008); Reay \& } \\
\text { Hinings (1995); } \\
\text { Zietsma \& Lawrence } \\
\text { (2010) }\end{array}$ \\
\hline $\begin{array}{l}\text { Fragmented } \\
\text { to aligned }\end{array}$ & Converging & $\begin{array}{l}\text { Emerging field, disparate actors } \\
\text { begin to converge on rules, } \\
\text { positions and actions. }\end{array}$ & $\begin{array}{l}\text { New actors, new } \\
\text { government } \\
\text { legislation, new } \\
\text { technology, field } \\
\text { configuring event }\end{array}$ & $\begin{array}{l}\text { Lægreid \& Serigstad } \\
\text { (2006); McInerny } \\
\text { (2008); Oliver \& } \\
\text { Montgomery (2008) }\end{array}$ \\
\hline $\begin{array}{l}\text { Fragmented } \\
\text { to contested }\end{array}$ & Converging & $\begin{array}{l}\text { Emerging field, yet direction is } \\
\text { still contested; rules, roles and } \\
\text { positions are a source of } \\
\text { struggle. }\end{array}$ & $\begin{array}{l}\text { FCE, SMO sub field } \\
\text { gathering disparate } \\
\text { actors }\end{array}$ & $\begin{array}{l}\text { Furnari (2014); } \\
\text { Hoffman (1999); } \\
\text { Maguire, Hardy, \& } \\
\text { Lawrence (2004) }\end{array}$ \\
\hline $\begin{array}{l}\text { Contested to } \\
\text { aligning }\end{array}$ & Converging & $\begin{array}{l}\text { Field is in process of emerging } \\
\text { and settling, disputes and rules } \\
\text { getting worked out, incremental } \\
\text { convergence on rules, roles and } \\
\text { positions; issue based field } \\
\text { becoming an exchange field. }\end{array}$ & $\begin{array}{l}\text { FCE, new actors, new } \\
\text { law }\end{array}$ & $\begin{array}{l}\text { Meyer, Gaba, \& } \\
\text { Colwell (2005); } \\
\text { Raaijmakers et al. } \\
\text { (2015); Zietsma \& } \\
\text { Lawrence (2010) }\end{array}$ \\
\hline $\begin{array}{l}\text { Contested to } \\
\text { established }\end{array}$ & Converging & $\begin{array}{l}\text { Field settled (abruptly), new } \\
\text { law or actor settles field } \\
\text { disputes; elites emerge and } \\
\text { shape positions and activity; } \\
\text { often a second-order move as } \\
\text { assumes prior field. }\end{array}$ & SMO - central & $\begin{array}{l}\text { Borum (2004); } \\
\text { Greenwood \& Suddaby } \\
\text { (2006); Yoshikawa, } \\
\text { Tsui-Auch, \& McGuire } \\
\text { (2007) }\end{array}$ \\
\hline
\end{tabular}


Table 5. Analysis of Sample Studies

\begin{tabular}{|c|c|c|c|c|c|c|c|}
\hline Article & Context & $\begin{array}{l}\text { Field Type: } \\
\text { Exchange } \\
\text { or Issue }\end{array}$ & $\begin{array}{l}\text { Sub- } \\
\text { field } \\
\text { Type }\end{array}$ & $\begin{array}{l}\text { Pathway: } \\
\text { Condition } \\
\text { moves }\end{array}$ & $\begin{array}{l}\text { Trigger for } \\
\text { Change: } \\
\text { Description }\end{array}$ & Agency & $\begin{array}{l}\text { Pathway Description: Scope, } \\
\text { Pace, Linearity }\end{array}$ \\
\hline $\begin{array}{l}\text { Anand, N., \& Jones, B. C. } \\
\text { (2008). Tournament rituals, } \\
\text { category dynamics, and field } \\
\text { configuration: The case of the } \\
\text { Booker Prize. Journal of } \\
\text { Management Studies, 45(6), } \\
\text { 1036-1060. }\end{array}$ & $\begin{array}{l}\text { Booker } \\
\text { Prize, } \\
\text { field con- } \\
\text { figuring } \\
\text { events, }\end{array}$ & Exchange & $\begin{array}{l}\text { Indus- } \\
\text { try }\end{array}$ & $\begin{array}{l}\text { Established, } \\
\text { contested, } \\
\text { aligning, } \\
\text { established }\end{array}$ & $\begin{array}{l}\text { Institutional } \\
\text { entrepreneurs } \\
\text { create new } \\
\text { category by } \\
\text { convincing } \\
\text { incumbent to } \\
\text { support }\end{array}$ & $\begin{array}{l}\text { Central actors, } \\
\text { arbiters of } \\
\text { taste introduce } \\
\text { new category }\end{array}$ & $\begin{array}{l}1969-1982 \text { : Incremental and } \\
\text { convergent change through use of } \\
\text { rituals, but transformative in } \\
\text { longer term, (and makes a } \\
\text { coherent and identifiable field) }\end{array}$ \\
\hline $\begin{array}{l}\text { Child, J., Lu, Y., \& Tsai, T. } \\
\text { (2007). Institutional } \\
\text { entrepreneurship in building an } \\
\text { environmental protection system } \\
\text { for the People's Republic of } \\
\text { China. Organization Studies, } \\
\text { 28(7), 1013-1034. }\end{array}$ & $\begin{array}{l}\text { China's } \\
\text { environ- } \\
\text { mental } \\
\text { protect- } \\
\text { tion } \\
\text { system }\end{array}$ & Issue & $\begin{array}{l}\text { Brid- } \\
\text { ging }\end{array}$ & $\begin{array}{l}\text { Fragmented, } \\
\text { aligning, } \\
\text { established }\end{array}$ & $\begin{array}{l}\text { Exogenous } \\
\text { shocks } \\
\text { (pollution } \\
\text { events), } \\
\text { government } \\
\text { prioritization }\end{array}$ & $\begin{array}{l}\text { Formal } \\
\text { governance } \\
\text { units (new } \\
\text { regulations), } \\
\text { new actors and } \\
\text { field } \\
\text { coordinators }\end{array}$ & $\begin{array}{l}30 \text { year analysis of development } \\
\text { of China's environmental } \\
\text { protection system, and how in } \\
\text { different periods, actors slowly } \\
\text { shaped the trajectory (less radical } \\
\text { change, but transformative when } \\
\text { taking longer term view) }\end{array}$ \\
\hline $\begin{array}{l}\text { Granqvist, N. and Laurila, J. } \\
\text { (2011). Rage against Self- } \\
\text { replicating Machines: Framing } \\
\text { Science and Fiction in the US } \\
\text { Nanotechnology Field. } \\
\text { Organization Studies, 32(2): } \\
\text { 253-280. }\end{array}$ & $\begin{array}{l}\text { Nanotech- } \\
\text { nology }\end{array}$ & Issue & $\begin{array}{l}\text { Inter- } \\
\text { stitial }\end{array}$ & $\begin{array}{l}\text { Fragmented, } \\
\text { aligning, } \\
\text { contested, } \\
\text { aligning }\end{array}$ & $\begin{array}{l}\text { SMO draws } \\
\text { in industry, } \\
\text { science, } \\
\text { government; } \\
\text { they } \\
\text { professiona- } \\
\text { lize and } \\
\text { ignore SMO }\end{array}$ & $\begin{array}{l}\text { Peripheral } \\
\text { actor, } \\
\text { institutional } \\
\text { entrepreneur, } \\
\text { professional } \\
\text { domination, } \\
\text { boundary work }\end{array}$ & $\begin{array}{l}\text { Study of emergence of field from } \\
1985 \text { to } 2006 \text {, radical technology } \\
\text { is incrementally supported } \\
\text { through social movement } \\
\text { processes, eventually developing } \\
\text { into its own field }\end{array}$ \\
\hline $\begin{array}{l}\text { Greenwood, R., \& Suddaby, R. } \\
\text { (2006). Institutional } \\
\text { entrepreneurship in mature } \\
\text { fields: The big five accounting } \\
\text { firms. Academy of Management } \\
\text { Journal, 49(1), 27-48. }\end{array}$ & $\begin{array}{l}\text { Account- } \\
\text { ing }\end{array}$ & Exchange & $\begin{array}{l}\text { Profes- } \\
\text { sional }\end{array}$ & $\begin{array}{l}\text { Established, } \\
\text { contested, } \\
\text { aligning, } \\
\text { established }\end{array}$ & $\begin{array}{l}\text { Elites } \\
\text { introduce } \\
\text { new } \\
\text { organization- } \\
\text { al form }\end{array}$ & $\begin{array}{l}\text { Central/elite } \\
\text { actor (also as } \\
\text { boundary } \\
\text { spanner) }\end{array}$ & $\begin{array}{l}\text { Retrospective study of specific } \\
\text { field organizational structure } \\
\text { change from 1977-2002; } \\
\text { evolutionary process of } \\
\text { embedding and responding to } \\
\text { field and external pressure }\end{array}$ \\
\hline $\begin{array}{l}\text { Hargadon, A. B., \& Douglas, Y. } \\
\text { (2001). When innovations meet } \\
\text { institutions: Edison and the } \\
\text { design of the electric light. } \\
\text { Administrative Science } \\
\text { Quarterly, 46(3), 476-501. }\end{array}$ & $\begin{array}{l}\text { Electric } \\
\text { light }\end{array}$ & Exchange & $\begin{array}{l}\text { Indus- } \\
\text { try }\end{array}$ & $\begin{array}{l}\text { Established, } \\
\text { (re)aligning, } \\
\text { established }\end{array}$ & $\begin{array}{l}\text { New } \\
\text { technology }\end{array}$ & $\begin{array}{l}\text { New actors, } \\
\text { field } \\
\text { coordinators, } \\
\text { central/elite } \\
\text { actors }\end{array}$ & $\begin{array}{l}1878 \text { to } 1886: \text { entrepreneur } \\
\text { achieved (historically) radical } \\
\text { change, the scope substantial over } \\
\text { this focused period yet longer } \\
\text { term impact generational }\end{array}$ \\
\hline
\end{tabular}




\begin{tabular}{|c|c|c|c|c|c|c|c|}
\hline Article & Context & $\begin{array}{l}\text { Field Type: } \\
\text { Exchange } \\
\text { or Issue }\end{array}$ & $\begin{array}{l}\text { Sub- } \\
\text { field } \\
\text { Type }\end{array}$ & $\begin{array}{l}\text { Pathway: } \\
\text { Condition } \\
\text { moves }\end{array}$ & $\begin{array}{l}\text { Trigger for } \\
\text { Change: } \\
\text { Description }\end{array}$ & Agency & $\begin{array}{l}\text { Pathway Description: Scope, } \\
\text { Pace, Linearity }\end{array}$ \\
\hline $\begin{array}{l}\text { Hoffman, A. J. (1999). } \\
\text { Institutional evolution and } \\
\text { change: Environmentalism and } \\
\text { the US chemical industry. } \\
\text { Academy of Management } \\
\text { Journal, 42(4), 351-371. }\end{array}$ & $\begin{array}{l}\text { US } \\
\text { chemical } \\
\text { industry/ } \\
\text { enviro, } \\
\text { case }\end{array}$ & Issue & $\begin{array}{l}\text { Comp- } \\
\text { etitive }\end{array}$ & $\begin{array}{l}\text { Established, } \\
\text { fragmented, } \\
\text { aligning, } \\
\text { established, } \\
\text { fragmented }\end{array}$ & $\begin{array}{l}\text { Multiple (and } \\
\text { different } \\
\text { types of) } \\
\text { events over } \\
\text { time }\end{array}$ & $\begin{array}{l}\text { All actor } \\
\text { positions, field } \\
\text { coordinators }\end{array}$ & $\begin{array}{l}\text { Analysis of field of activity from } \\
\text { 1960-1993, including participants, } \\
\text { materials, discourse, events (some } \\
\text { disruptive); slow and incremental } \\
\text { change that is transformative } \\
\text { when viewed over longer time } \\
\text { period. }\end{array}$ \\
\hline $\begin{array}{l}\text { Kitchener, M. (2002). } \\
\text { Mobilizing the logic of } \\
\text { managerialism in professional } \\
\text { fields: The case of academic } \\
\text { health center mergers. } \\
\text { Organization Studies, 23(3), } \\
\text { 391-420. }\end{array}$ & $\begin{array}{l}\text { Academic } \\
\text { health } \\
\text { centres }\end{array}$ & Exchange & $\begin{array}{l}\text { Indus- } \\
\text { try, } \\
\text { Profes- } \\
\text { sional }\end{array}$ & $\begin{array}{l}\text { Fragmented, } \\
\text { aligning }\end{array}$ & $\begin{array}{l}\text { External field } \\
\text { pressure, } \\
\text { competition }\end{array}$ & $\begin{array}{l}\text { All actor } \\
\text { positions }\end{array}$ & $\begin{array}{l}\text { Focused analysis in a short period } \\
\text { of time (approx 1999), drawing on } \\
\text { qualitative investigation of how } \\
\text { societal level myths and pressures } \\
\text { play out and impact at field level, } \\
\text { driving change in key actor }\end{array}$ \\
\hline $\begin{array}{l}\text { Lounsbury, M., \& Crumley, E. } \\
\text { T. (2007). New practice creation: } \\
\text { An institutional perspective on } \\
\text { innovation. Organization } \\
\text { Studies, 28(7), 993-1012. }\end{array}$ & $\begin{array}{l}\text { Mutual } \\
\text { fund } \\
\text { industry }\end{array}$ & Exchange & $\begin{array}{l}\text { Indus- } \\
\text { try }\end{array}$ & $\begin{array}{l}\text { Established, } \\
\text { contested, } \\
\text { established }\end{array}$ & Experiments & $\begin{array}{l}\text { New actors, } \\
\text { Central/elite } \\
\text { actors }\end{array}$ & $\begin{array}{l}\text { Historical case study, focusing on } \\
\text { decades from } 1930 \text { s to } 1960 \text { s, on } \\
\text { incremental changes and } \\
\text { introduction of new practices and } \\
\text { their adoption and } \\
\text { institutionalization in field }\end{array}$ \\
\hline $\begin{array}{l}\text { Maguire, S., Hardy, C., \& } \\
\text { Lawrence, T. B. (2004). } \\
\text { Institutional entrepreneurship in } \\
\text { emerging fields: HIV/AIDS } \\
\text { treatment advocacy in Canada. } \\
\text { Academy of Management } \\
\text { Journal, 47(5), 657-679. }\end{array}$ & $\begin{array}{l}\text { HIV/ } \\
\text { AIDS } \\
\text { treatment }\end{array}$ & Issue & $\begin{array}{l}\text { Inter- } \\
\text { stitial }\end{array}$ & $\begin{array}{l}\text { Fragmented, } \\
\text { aligning, } \\
\text { established }\end{array}$ & $\begin{array}{l}\text { Issue, } \\
\text { exogenous } \\
\text { shock } \\
\text { (disease) }\end{array}$ & $\begin{array}{l}\text { Peripheral } \\
\text { actors, new } \\
\text { actors, field } \\
\text { coordinators }\end{array}$ & $\begin{array}{l}\text { Twenty year case study from } 1980 \\
-2000 \text {, role of institutional } \\
\text { entrepreneurs in radically } \\
\text { transforming field especially } \\
\text { between } 1995 \text { and } 2000 .\end{array}$ \\
\hline $\begin{array}{l}\text { Zietsma, C., \& Lawrence, T. B. } \\
\text { (2010). Institutional Work in the } \\
\text { Transformation of an } \\
\text { Organizational Field: The } \\
\text { Interplay of Boundary Work and } \\
\text { Practice Work. Administrative } \\
\text { Science Quarterly, 55(2), 189- } \\
221 .\end{array}$ & $\begin{array}{l}\text { Forestry, } \\
\text { Canada }\end{array}$ & Issue & $\begin{array}{l}\text { Comp- } \\
\text { etitive }\end{array}$ & $\begin{array}{l}\text { Established, } \\
\text { contested, } \\
\text { aligning }\end{array}$ & $\begin{array}{l}\text { Social } \\
\text { movement }\end{array}$ & $\begin{array}{l}\text { New actors, } \\
\text { formal } \\
\text { governance } \\
\text { units, field } \\
\text { coordinators }\end{array}$ & $\begin{array}{l}\text { Longitudinal analysis of a field } \\
\text { level conflict involving contests } \\
\text { over boundaries and practices } \\
\text { over a } 20 \text { year period. Radical } \\
\text { change yet slow pace in the } \\
\text { realignment of field, over this } \\
\text { period. }\end{array}$ \\
\hline
\end{tabular}


